AGU Geodynamics Series Volume 30, PLATE BOUNDARY ZONES

Edited by Seth Stein and Jeffrey T. Freymueller, p. 295-324

\title{
A Dangling Slab, Amplified Arc Volcanism, Mantle Flow and Seismic Anisotropy in the Kamchatka Plate Corner
}

\author{
Jeffrey Park, ${ }^{1}$ Vadim Levin, ${ }^{1}$ Mark Brandon, ${ }^{1}$ Jonathan Lees, ${ }^{2}$ Valerie Peyton, ${ }^{3}$ Evgenii \\ Gordeev, ${ }^{4}$ Alexei Ozerov, \\ Book chapter in press with "Plate Boundary Zones," edited by Seth Stein and Jeffrey Freymuller
}

\begin{abstract}
The Kamchatka peninsula in Russian East Asia lies at the junction of a transcurrent plate boundary, aligned with the western Aleutian Islands, and a steeply-dipping subduction zone with near-normal convergence. Seismicity patterns and $P$-wave tomography argue that subducting Pacific lithosphere terminates at the Aleutian junction, and that the downdip extension $(>150 \mathrm{~km}$ depth) of the slab edge is missing. Seismic observables of elastic anisotropy ( $S K S$ splitting and Love-Rayleigh scattering) are consistent with asthenospheric strain that rotates from trench-parallel beneath the descending slab to trench-normal beyond its edge. Present-day arc volcanism is concentrated near the slab edge, in the Klyuchevskoy and Sheveluch eruptive centers. Loss of the downdip slab edge, whether from thermo-convective or ductile instability, and subsequent "slab-window" mantle return flow is indicated by widespread Quaternary volcanism in the Sredinny Range inland of Klyuchevskoy and Sheveluch, as well as the inferred Quaternary uplift of the central Kamchatka depression. The slab beneath Klyuchevskoy has shallower dip $\left(35^{\circ}\right)$ than the subduction zone farther south $\left(55^{\circ}\right)$ suggesting a transient lofting of the slab edge, either from asthenospheric flow or the loss of downdip load. Such lofting may induce pressure-release melting to supply the Klyuchevskoy and Sheveluch eruptive centers. Petrologic indicators of high magma-peridotite equilibrium temperatures, long residence times for the hydrous arc-volcanic component, and weak expression of subducted sediment flux support the lofting hypothesis, and discourage an alternate interpretation in terms of accelerated slab rollback and/or a heightened influx of subducted volatiles. Over the late Cenozoic, the Komandorsky Basin subducted beneath northern Kamchatka and produced arc volcanics in the Sredinny Range. Several lines of evidence suggest the northeast migration of a plate triple junction (North America/Pacific/Komandorsky) along the eastern Kamchatka coast in Oligocene-Miocene times. Three "Cape terranes" (Shipunsky, Kronotsky, Kamchatka) along the coastline are exotic, with geologic similarities to present-day western Aleutian islands, and may have accreted in a "caulking-gun" process as the triple junction migrated NE. The late Cenozoic transfer of arc volcanism from the Sredinny Range to the eastern volcanic front of Kamchatka may have been facilitated by the progressive replacement of a shallow-dipping Komandorsky slab with a steeply-dipping Pacific slab.
\end{abstract}




\section{INTRODUCTION}

The Kamchatka peninsula marks the northeastern edge of the Pacific plate. The many volcanoes of the peninsula glow brightly in the Pacific "ring of fire." The modern plate kinematics of the Kamchatka region are deceptively simple (Figure 1). The Aleutian Islands of Alaska trend SE-NW along the strike-slip Bering fault zone between the Pacific and North American plates [Geist and Scholl, 1994; Seliverstov, 1997; 1998], terminating against Cape Kamchatka at $56^{\circ} \mathrm{N}$. South of the Bering fault, a subduction zone with rapid normal convergence $(80 \mathrm{~mm} / \mathrm{yr}$ according to NUVEL-1 [DeMets, 1992a]) lies offshore southern Kamchatka, trending to the SW in a gentle arc towards the Kurile and North Japan subduction zones. Within southern Kamchatka a line of arc volcanoes lies above a moderate-to-steeply dipping Wadati-Benioff zone roughly where seismicity reaches a depth of $500 \mathrm{~km}$ [Gorbatov et al., 1997]. In the standard model for arc-volcanism, dehydration of the slab occurs near this depth, and is assumed to flush the overriding mantle wedge with volatiles and induce partial melting [Winter, 2001]. Volcanism in the western Aleutians is inactive, by contrast, as no subduction occurs along the Bering Fault zone.

Viewed in more detail, the Pacific plate boundary in the Kamchatka region presents a number of complications. In the conventional demarcation of plate boundaries, Kamchatka and eastern Siberia constitute the western extremity of the North American plate [Cook et al., 1986; DeMets et al., 1990; Kogan et al., 2000], despite their continuity with Eurasia. The late-Cenozoic tectonics of the North American plate west of the Alaskan mainland have been far from rigid. North of the Aleutian junction, the Kamchatka coastline borders an inactive subduction zone. Convergence of young oceanic plate and concomitant arc volcanism in northern Kamchatka persisted until at least $10 \mathrm{Ma}$, supplied by a spreading center in the Komandorsky Basin northeast of the Bering Fault zone [Cormier, 1975; Hochstaedler et al., 1994]. In addition to ocean-continent convergence, the Aleutian island arc has collided edgewise with the Kamchatka peninsula. Geist and Scholl [1994] argue that Cape Kamchatka itself (Figure 2) represents the collision of an Aleutian island with the Eurasian mainland, an idea anticipated by Markov et al. [1969]. In the Kamchatka back-arc region, the lithosphere of the Okhotsk Sea has been characterized variously as a continental extension zone [Gnibidenko and Khvedchuk, 1982; Gnibidenko et al., 1995; Melankholina,
1998] or an independent rigid-plate fragment [e.g., Cook et al., 1986; Riegel et al., 1993; Konstantinovskaia, 2001]. On a smaller spatial scale, southern Kamchatka is split by an axial depression that separates the peninsular topography into an eastern volcanic chain and the western Sredinny Range [Fedotov and Masurenkov, 1991] (Figure 3). The Sredinny Range is now largely inactive both volcanically and tectonically.

Kamchatka is one of the few places in the world where land-based observations can probe the upper mantle at and beyond the terminus of a mature subduction zone. Near the Aleutian-Kamchatka corner, the subduction zone lacks deep earthquakes, and Benioff-zone dip decreases from $55^{\circ}$ to $35^{\circ}$ [Gorbatov et al., 1997]. Active volcanism shifts inland to follow the shallowing slab, terminating in the Klyuchevskoy and Sheveluch volcanic centers. The inland shift steps out of the Eastern Volcanic Front (EVF) and into the flat-lying Central Kamchatkan Depression (CKD). Although the topography of the CKD resembles an extensional graben, the region lacks surface manifestations of volcanic basement rocks. Nevertheless, Klyuchevskoy is the most active island arc volcano on the Pacific rim. Does the Pacific slab terminate here? If so, does the slab-edge volcanism of Klyuchevskoy represent a transient or steady-state tectonic process?

Kamchatka and the western Aleutians host many examples of a peculiar type of arc volcanism, termed "adakites" [Hochstaedler et al., 1994; Kepezhinskas et al., 1996; Yogodzinski et al., 2001]. "Adakites" possess a high $\mathrm{Mg}$ content and unusual trace element ratios, commonly interpreted to imply a meltcontribution from the subducted oceanic crust, in addition to the fluid component from slab dehydration. Most adakite locales occur where young oceanic lithosphere subducts and retains warmth sufficient to allow partial melting of its crust [Drummond and Defant, 1990; Defant and Kepezhinskas, 2001]. The subducting plate in the Kamchatka region is $\sim 70-100 \mathrm{My}$ old, depending on the exact location along the NE Pacific plate margin, and does not fit the scenario of young, warm oceanic lithosphere. However, the only active volcanism with an adakite signature occurs at Sheveluch, which lies at or just beyond the presumed Pacific plate slab edge in central Kamchatka. What factors might encourage this style of volcanism near the edge of the plate?

Seismic waves may help resolve the mantle-flow kinematics that underpin the observed plate kinemat- 
ics, and suggest dynamic models for the Kamchatka region. Tomography can detect lateral variation of fast and slow velocity anomalies in the mantle, and suggest the presence or absence of cold (fast) slab and warm (slow) asthenosphere. Mantle flow may cause elastic anisotropy in strained peridotite [Christensen, 1984; Ribe, 1992; Zhang and Karato, 1995; Zhang et al., 2000], and can be detected by shear-wave splitting [Vinnik et al., 1984; Silver and Chan, 1991], Ps converted phases in body-wave receiver functions [Levin and Park, 1997; Bostock, 1998], and Love-to-Rayleigh surface-wave scattering [ $Y u$ and Park, 1994].

Mantle dynamics in the Kamchatka region hinge on tectonic mechanisms whose application to the region is still largely hypothetical. Several scenarios are plausible. When oceanic lithosphere subducts into the mantle, it may undergo trench-axis rollback [Dewey, 1980; Kincaid and Olson, 1987; Otsuki, 1989; Royden and Burchfiel, 1989], in which the asthenosphere under the slab is pushed either downward or along the trench towards the "free" end of the subduction zone. Flow in the mantle wedge is often conceptualized in terms of a 2-D corner flow driven by shearcoupling to the downgoing slab [Ida, 1983; Peacock and Wang, 1999]. Trench-parallel flow on the seaward side of the trench has been proposed for a variety of convergent settings [Alvarez, 1982; Kaneshima and Silver, 1992; Russo and Silver, 1994; 1996; Yu and Park, 1994], and simulated in physical analog experiments [Buttles and Olson, 1998]. In some situations the subducting slab is thought susceptible to thermal instabilities [Davaille and Lees, 2002] or ductile necking and detachment [Davies and von Blankenburg, 1995]. Such processes may help explain why the Wadati-Benioff zone under central Kamchatka lacks deep seismicity.

In the former USSR, the Institute of Volcanology and the Experimental-Methodical Seismic Department (KEMSD) coordinated geophysical research aimed at the active volcanoes and earthquake zones of Kamchatka. In the 1990s these institutes reorganised within the Russian Academy of Sciences, and there have been many collaborations between Russian and outside scientists to study volcanic processes and petrology, to measure geodetic movements, and to probe the seismic structure of the region. This paper attempts a synthesis of recent geological investigations of the Kamchatka plate boundaries, and so highlights a range of tectonic scenarios that may be tested with future field observations and studies of existing data. A re-evaluation of Kamchatka tec- tonics is motivated by seismic data from the "Side Edge of Kamchatka Slab" (SEKS) deployment of 15 broadband portable seismometers in 1998-1999 [Lees et al., 2000]. Section 2 discusses the tectonic setting of the Kamchatka region, including geologic terrane identification, geodetic constraints and plate-tectonic reconstructions. Section 3 discusses earthquakes and seismic velocity structure in the region, with a focus on slab location and structure. Section 4 discusses seismic indicators of mantle flow, both near the slab edge and in the mantle wedge. Section 5 discusses igneous processes, both primary lava characteristics and indicators from mantle xenoliths, the latter of which are unusually common in the region. In Section 6 we discuss several scenarios for mantle kinematics in the Kamchatka region. Many predictions of these scenarios are poorly constrained at present; we suggest how the constraints might be improved.

\section{TECTONIC SETTING}

From its southern tip to the Koryak highlands, the Kamchatka peninsula extends more than $1600 \mathrm{~km}$, similar to the distance between the cities of Los Angeles and Seattle along the western margin of North America. The peninsula varies in width from 100 $\mathrm{km}$ in its northern isthmus to $400 \mathrm{~km}$ at its widest in the south (Figure 2). Subduction has shaped the entire eastern coastline of Kamchatka, but is active only beneath the southern half of the peninsula, extending roughly $700 \mathrm{~km}$ between its junctions with the Kurile and Aleutian island chains. Subduction of the Pacific plate is near-normal to the plate boundary, which turns at a right angle at Cape Kamchatka to become transcurrent. The inactive volcanic islands of the western Aleutians lie along the transcurrent boundary, which also divides geographically the Pacific Ocean from the Bering Sea. Past subduction in the north is indicated by an inactive chain of volcanic mountains along the spine of the isthmus [Hochstaedler et al., 1994; Kepezhinskas et al., 1997], uplifted foredeep sediments exposed offshore on Karaginsky Island [Kovalenko et al., 1999], and late Cenozoic seafloor spreading in the Komandorsky Basin of the western Bering Sea [Seliverstov, 1997; 1998]. On its western side, Kamchatka is separated from Eurasia by the Okhotsk Sea.

The volcanic Sredinny Range, now inactive, runs along the northern isthmus and the center of southern Kamchatka (Figure 3). From the Kuriles to Cape Kamchatka, an Eastern Volcanic Front (EVF) is pop- 
ulated by numerous active and inactive volcanic centers. Between the two highland ranges lies the Central Kamchatka Depression (CKD) extending from inland of Petropavlovsk-Kamchatsky to the Bering Sea. Within the CKD lie the northernmost active volcanoes of the western Pacific plate boundary, dominated by Sheveluch and the group of volcanic centers surrounding Klyuchevskoy. From its southern extreme, the Kamchatka River runs northeast along the CKD, turning seaward between Klyuchevskoy and Sheveluch volcanoes to a mouth at the Pacific just south of Cape Kamchatka.

\subsection{Accreted Terranes and the Origin of Kamchatka}

Russian East Asia is composed of Mesozoic terranes that accreted to Eurasia [Watson and Fujita, 1985; Stavsky et al., 1990; Zonenshain et al., 1990; Bogdanov et al., 1990; Worrall, 1991; Til'mann and Bogdanov, 1992; Zinkevich and Tsukanov, 1993; Geist and Scholl, 1994; Geist et al., 1994; Shapiro, 1995; Seliverstov, 1998; Shapiro et al., 1997; Pechersky et al., 1997; Konstantinovskaya, 1999; Nokleberg et al. 1997; 2001] as recently as the mid-Eocene ( 43 Ma) [Garver et al., 2000; Soloviev et al., 2001]. Kamchatka was formed by accretion of island-arc terranes to the Okhotsk-Chukotka volcanic belt of eastern Siberia, which was active from the mid- to late Cretaceous (Figure 4). A complex succession of terranes connects the main peninsula to the Eurasian mainland. This zone is termed the Koryak system by Zonenshain et al. [1990], and includes numerous flysch units and ophiolites [Alekseyev, 1987]. These units attest to the accumulation of thick terrestrial sediments on the continental margin, and to the consumption of ocean basins as accretion proceeded.

Thrust over the so-called Ukelayet flysch in spectacular exposures in the Koryak highlands of northern Kamchatka, the Olyutorsky terrane (termed the Achaivayam-Valaginsky arc (AVA) by Shapiro [1995], Shapiro et al. [1997] and Konstantinovskaya [1999; 2001]) was the last major terrane to attach itself to the peninsula [Fujita and Newberry, 1983; Geist et al., 1994], although minor terranes have since accreted (see below). The Olyutorsky terrane extends along nearly the full length of the Kamchatka peninsula, and may include the Shirshov and Bowers Ridges of the Bering Sea, both now submerged. The emplacement of the Olyutorsky terrane is argued by Garver et al. [2000] to have occurred near $43 \mathrm{Ma}$. This date coincides with the sharp mid-Eocene shift in Pacific plate motion, as recorded by the bend in the HawaiiEmperor hotspot chain, but no causal connection has yet been proposed. In the northwest Pacific at this time, Pacific plate motion switched from northward to west-northwest. Subduction and volcanism in the western Aleutians ceased in favor of right-lateral transcurrent motion, which has continued into the present [Yogodzinsky et al., 1993]. The collision of the Olyutorsky terrane with Eurasia may have influenced the Pacific plate-velocity change, but a detailed assessment of this relationship remains to be made.

Shapiro [1995] argues, from an inferred shortage of coeval arc volcanism along the Eurasian margin, that prior to collision the Olyutorsky arc lay over a southeast-dipping subduction zone. In this scenario, the arc overrode the Eurasian continental margin during collision. In the Koryak highlands of northern Kamchatka, Garver et al. [2000] report a continuous supply of detrital zircons to the Ukelayet flysch from the erosion of a nearby continental arc during the Campanian through Eocene, which may weaken the assertion by Shapiro [1995] that subduction ceased along the Eurasian margin in the latest Cretaceous. Assuming southeast-dipping subduction under the Olyutorsky terrane, Konstantinovskaya [1999] argues that subduction polarity switched after collision according to the model of Chemenda et al. [1995]. In this scenario, the Ganal and Sredinny metamorphic terranes in south Kamchatka represents burial, heating and later exhumation of partially subducted sediments. Konstantinovskaia [2001] notes, however, that no exhumed high-pressure/low-temperature metamorphic rocks have been found along the trace of the potential subduction-polarity reversal. Chemenda et al. [1995] predict such "blueschist" metamorphism to be exhumed in their model.

Since the Olyutorsky emplacement, three exotic terranes have accreted to the Pacific coast of Kamchatka. From south to north, these form the coastal peninsulas of Cape Shipunsky, Cape Kronotsky, and Cape Kamchatka [Konstantinovskaya, 1999]. The last of these is identified by Shapiro [1980] and Geist et al. [1994] as a former volcanic island of the Aleutian arc, presently thrusting onto Eurasia in a broad crustal deformation zone. Paleomagnetic data have demonstrated that Cape Kamchatka was far south of Kamchatka in the early Tertiary (66-36 Ma) [Bazhenov et al., 1991; Pechersky et al., 1997]. Transcurrent motion along the western Aleutians appears to be distributed between right-lateral strike-slip faults on both sides of the island chain [Ekstrom and Eng- 
dahl, 1989; Geist and Scholl, 1992; Gaedicke et al., 2000]. The western Aleutian arc apparently converges against Kamchatka as a result of shear-coupling with the Pacific plate, albeit at a slower rate.

\subsection{Cenozoic Kinematics of the Komandorsky Basin}

In recent plate reconstructions, the Komandorsky Basin originated as a remnant patch of the Pacific plate, adjacent to the Olyutorsky terrane, and was later isolated by trench-parallel motion of the western Aleutian arc [Seliverstov, 1998; Nokleberg et al., 2001]. Northeast of the western Aleutians in the Bering Sea, the Komandorsky Basin underwent an episode of margin-parallel spreading in the late Cenozoic [Baranov et al., 1991]. Margin-parallel backarc spreading is uncommon, but consistent with the observation by Jurdy [1979] that spreading directions in Pacific marginal basins tend to align with the motion of the downgoing plate. Jurdy and Stefanick [1983] modelled backarc spreading as a response of the overriding plate to a transient stress increase induced by a velocity change in the downgoing slab. A portion of the Pacific lithosphere likely subducted beneath the western Aleutians in the mid-Eocene, and later shifted its motion to (largely) trench-parallel, forming a transcurrent plate boundary. In the $J u$ $r d y$ [1979] scenario, stresses transmitted through the mantle wedge by this change in slab motion would have induced back-arc spreading. Jurdy [1979] interprets magnetic data from marginal seas to argue that backarc spreading starts roughly $5 \mathrm{Ma}$ after a change in slab velocity, and lasts no longer than a few tens of My. Spreading in the basin is now inactive, and Honthaas et al. [1995] report that one sample of Komandorsky basin crust has yielded an age of 9.3 Ma. Taking the Olyutorsky collision to occur near $43 \mathrm{Ma}$ [Garver et al., 2000], and additional time for the western Aleutians to collide with Kamchatka, this suggests a maximum $\sim 25$ My duration for Komandorsky spreading.

The production of new oceanic crust in the Komandorsky Basin was compensated (and perhaps overcompensated) by subduction along the western coastline of northern Kamchatka, as indicated by past volcanism in the Sredinny Range [Zonenshain et al., 1990]. Honthaas et al. [1995] report dated volcanic rocks in the northern Sredinny Range, ranging from 5.7-12 $\mathrm{Ma}$, as well as rocks $36 \mathrm{Ma}$ and older. Hochstaedler et al. [1994] note that volcanic rocks younger than $10 \mathrm{Ma}$ in the Valovayam local- ity lack strong subduction trace-element signatures, which suggests that Komandorsky-plate subduction in northern Kamchatka may have weakened or stalled after $10 \mathrm{Ma}$.

\subsection{The Okhotsk Sea: Independent Plate or Extended Continent?}

To the west of Kamchatka lies the Okhotsk Sea (Figure 1). Some researchers hypothesize the existence of an Okhotsk microplate, bordered on the west by a transcurrent shear zone along Sakhalin Island, and on the south and east by the convergent Kuril-Kamchatka subduction zones [Cook et al., 1986; Riegel et al., 1993; Konstantinovskaia, 2001]. Plate reconstructions for Eastern Siberia commonly invoke the accretion of an Okhotsk terrane, at or near the emplacement time of the Olyutorsky terrane [e.g. $Z_{o-}$ nenshain et al., 1990]. The northern boundary of a hypothetical Okhotsk plate would be a belt of diffuse seismicity within the Cherskii orogenic belt along the northern coast of the Okhotsk Sea [Fujita et al., 1990; Riegel et al. 1993; Imaev et al. 2000]. Evidence for a plate boundary across the isthmus of northern Kamchatka is wanting, as no active tectonic structures displace the Sredinny Range significantly. Because its interior is covered with water, the argument for an independent Okhotsk plate depends on kinematic data from its seismogenic boundaries [Seno et al., 1996]. These data are subject to different interpretations. DeMets [1992ab] analysed earthquake focal mechanisms in the Kuriles in terms of plate boundary deformation associated with oblique subduction, rendering an Okhotsk plate unnecessary. Recent continuousGPS measurements, reported by Kogan et al. [2000], do not resolve this ambiguity, as stations at Magadan and Petropavlovsk-Kamchatsky appear to move in response to local tectonic processes.

The interpretation of the Okhotsk region in terms of an ancient accreted terrane is undermined by its continental nature, and by evidence for substantial extension of its crust in the Cenozoic [Gnibidenko and Khvedchuk, 1982; Jolivet 1987; Gnibidenko et al., 1995; Melankholina, 1998; Shapiro et al., 2000]. A more satisfactory analogue for Okhotsk tectonics may be the Tyrrhenian Sea of the Mediterranean region [Faccenna et al., 1997; Wortel and Spakman, 2000], where continental crust extended in response to the broad retreat of the Adriatic subduction zone beneath the Apennine mountains of Italy. Just as extreme extension of the southern Tyrrhenian Sea even- 
tually pulled apart continental crust to form oceanic lithosphere [Faccenna et al., 1997], the southward extension of Okhotsk envisioned by Jolivet [1987] may have generated the patch of oceanic lithosphere that lies just behind the Kurile arc. This interpretation is consistent with crustal thickness variations along the Kurile arc, $8-10 \mathrm{~km}$ beneath the central Kuriles, and $20-25 \mathrm{~km}$ beneath the northern and southern islands, which are closest to other continental crustal blocks [Bogatikov et al., 2000].

Okhotsk extension is a key corollary of trench migration and slab rollback in the northwest Pacific [Peyton et al., 2001]. The oceanic Kurile Basin lacks seafloor magnetic lineations that could constrain the timing and orientation of spreading [Gnibidenko et al., 1995], so typical constraints come from the age of sediment cover (timing) and the trends of structural features (orientation). North-south extension of the central and southern Okhotsk region, rotated to NE-SW extension near the right-lateral Sakhalin shear zone, is consistent with east-west and NW-SE trends of submarine grabens and normal faults [ $\mathrm{Jo}_{0}$ livet, 1987; Worrall et al., 1996]. Jolivet [1987] estimates north-south extension to occur in the early through mid-Miocene (10-25 Ma), implying a general retreat of the Kurile trench. In northern Okhotsk and the Kamchatka isthmus, Worrall et al. [1996] identify a set of left-lateral faults and pull-apart basins filled with Eocene-Oligocene sediments, suggestive of eastwest extension that was coeval and subsequent to the accretion of the Olyutorsky terrane. Worrall et al. [1996] propose that east-west extension occurred in response to the collision of India with Eurasia, simultaneous with the opening of Lake Baikal, but backarc stresses from the reorganization and/or retreat of the northwest Pacific subduction zones could also have been a factor. In fact, Northrup et al. [1995] argue that an Eocene-through-Miocene slowdown in the Pacific-Eurasian convergence rate, and associated compressional stresses, is responsible for many of the western Pacific marginal basins.

\section{SEISMOTECTONICS, VELOCITY STRUCTURE, AND THE SLAB}

Constraints on past plate kinematics in the Kamchatka region from surface geology are complemented by constraints of present-day plate dynamics from seismology. Earthquakes are a direct indicator of plate interaction, and seismotectonic diagrams can trace the path of brittle lithospheric material through the mantle. The mineralogy and anisotropic texture of the downgoing Pacific slab can be discerned from guided waves from deep-slab earthquakes, and by conversions of teleseismic $P$ waves to $S$ at the top of the slab. Seismic tomography can image the location of slow and fast elastic wavespeeds in the mantle, and suggest patterns of mantle flow. Finally, $P$ to $S$ converted phases from the Moho crust-mantle interface can be used to track crustal thickness and elastic properties.

\subsection{Earthquake Locations and the Slab Edge}

Kamchatka hosted many "great" earthquakes in the 20th century, e.g., in $1923\left(M_{s}=8.1\right), 1952\left(M_{W}=9.0\right)$, $1959\left(M_{s}=8.2\right), 1971\left(M_{s}=8.0\right)$, and $1997\left(M_{W}=7.8\right)$ [Burgmann et al., 2001]. Great earthquakes are also common in other subduction zones of the northwest Pacific, making the Kuriles-Kamchatka-western Aleutian segment of the Pacific plate boundary one of the most strongly-coupled in the world [Pacheco et al., 1993]. Burgmann et al., [2001] argues that the 5 December 1997 Kronotsky earthquake $\left(M_{W}=7.8\right)$ was followed by aseismic afterslip with moment release equal to the seismic event. Such a large strain accumulation is perhaps consistent with the strong coupling scenario. Weak seismic coupling, as measured by the proportion of plate-tectonic slip released as seismic moment, was found by Pacheco et al. [1993] to characterize subduction zones with active back-arc spreading. A "strengthening" of Pacific-North American plate interactions in the past 10 My may be related to the cessation of back-arc spreading in the Komandorsky Basin.

Using more than 20000 local earthquakes located in 1962-1990 by the Kamchatka Regional Seismic Network (KRSN), Gorbatov et al. [1997] map a downgoing Pacific plate that has deformed from stresses near the Benioff-zone terminus at the Aleutian junction. South of $54^{\circ} \mathrm{N}$ (approximately Cape Kronotsky), the Pacific slab subducts at a steep angle $\left(\sim 55^{\circ}\right)$. In this region, stresses inferred by Christova [2001] from deep-focus earthquake source mechanisms are not dominated by downdip extension, as one might expect during slab rollback. Instead, Christova [2001] identifies "frontal" and "in-slab" earthquake stresses that have opposite character at depths $>61 \mathrm{~km}$, suggesting an "unbending" of the slab as it descends below a strongly-coupled zone of shallow thrust earthquakes.

North of $54^{\circ} \mathrm{N}$, the slab dip shallows to $\sim 35^{\circ}$. The transition in apparent slab dip occurs over a narrow $(\sim 30 \mathrm{~km})$ interval of slab length along the trench, 
and is marked by an unusual concentration of small earthquakes at $60-100 \mathrm{~km}$ depth, where the dips begin to diverge [Gorbatov et al., 1997]. A source mechanism for one of the larger recorded earthquakes in the contorted zone $\left(M_{W}=5.8,22\right.$ March 1980) shows a stress pattern consistent with local plate torsion i.e. a trench-parallel bending stress. Gorbatov et al. [1997] notes that, with few exceptions, active volcanoes in Kamchatka lay above the $90-150-\mathrm{km}$ depth range of Benioff-zone seismicity, so that the change in slab dip correlates with an inland shift of volcanic activity from the Eastern Volcanic Front to the Central Kamchatka Depression.

Gorbatov et al. [1997] find deep-focus seismicity to depart from simple geometry near the slab edge. Deep-focus seismicity is less common in the Kamchatka Wadati-Benioff zone than beneath e.g., Japan, Fiji, and Tonga (Figure 5). However, south of $53^{\circ} \mathrm{N}$ scattered earthquakes occur deeper than $400 \mathrm{~km}$. The maximum depth of seismicity shallows to $200-300 \mathrm{~km}$ within the contortion zone near $54^{\circ} \mathrm{N}$, and shallows further to $\sim 100 \mathrm{~km}$ beneath the vigorous volcanic centers of Klyuchevskoy and Sheveluch. In the vicinity of its Aleutian terminus, therefore, the Pacific slab loses its defining characteristics at an unusually shallow depth.

Is the slab edge missing, or has the slab changed character? Shallow and intermediate-depth seismic activity in the Wadati-Benioff zone defines the volume of downgoing lithosphere that suffers brittle fracture. The seismogenic zone is likely cooler and therefore less ductile than surrounding mantle rock, but brittle rheology may also be fostered by rapid mineral phase changes from metastable thermal conditions [Kirby et al., 1996] and fluid-release embrittlement from overstepped dehydration metamorphism [Ague et al., 1998]. Thermal modelling [Gorbatov et al., 1997; Davaille and Lees, 2002] suggests that conductive heating of ordinary Pacific lithosphere is too slow to alter its brittle character. Gorbatov et al. [1997] suggest that the extreme edge of the Pacific plate is unusually thin when it enters the Kamchatka subduction zone, and therefore more prone to heating, due to thermal erosion associated with the Meiji seamounts of the Hawaii-Emperor hotspot track. Davaille and Lees [2002] suggest that lithosphere beneath the Hawaii-Emperor chain is no thinner than surrounding Pacific plate, but that a thermal anomaly inherited from the Hawaii hotspot induces delayed small-scale convection as the plate subducts. In Section 6 of this paper, we propose a third alter- native, based on Davies and von Blankenburg [1995], namely, that asthenospheric flow near the slab edge focuses tensional stress on it, and that a slab fragment has detached and sunk into the lower mantle as a result.

\subsection{Seismic Velocities and Slab Dynamics}

Aseismic slabs can be traced through the mantle with "fast" anomalies in seismic velocity, caused by their residual "cold" thermal anomalies. Using residual-sphere analysis, a method that maps teleseismic traveltime anomalies into the near-source region, Boyd and Creager [1991] suggested that "fast" velocities extended beyond the seismogenic zone in the western Aleutians. Although the events analysed were few and restricted to the western Aleutians, the residual-sphere analysis favored a "folded tablecloth" subduction geometry, in which the Pacific slab draped over the Aleutian-Kamchatka junction. Because subduction in the western Aleutians is inactive, Creager and Boyd [1991] proposes that Pacific lithosphere subducted at an oblique angle in the central Aleutians and then translated aseismically towards Kamchatka.

A regional $P$-wave tomographic study of the northwest Pacific subduction zones casts serious doubt on the "folded tablecloth" model [Gorbatov et al., 2000]. Fast anomalies that would be expected to dip northeast from the western Aleutians are not found, and the upper mantle beneath the seismogenic slab edge is anomalously slow ( $1 \%)$. The velocity images favor the loss of the slab edge, rather than its aseismic extension. Flat-lying velocity anomalies in the transition zone beneath the Bering Sea [Gorbatov et al., 2000] and the southern Okhotsk Sea [van der Hilst et al., 1991] have been interpreted as residual slabs emplaced by past trench rollback. Fast seismic velocity anomalies in the north Kuriles and southern Kamchatka appear to extend into the lower mantle, however, suggesting slab penetration and a firmer anchor for the subduction zone.

In a $P$-wave tomographic study restricted to stations and events in southern Kamchatka, Gorbatov et al. [1999] found larger $(\sim 6 \%)$ anomalies in seismic velocities than found in teleseismic studies. The slowest anomalies tended to cluster within the supraslab mantle wedge, directly beneath $(\sim 30 \mathrm{~km}$ depth $)$ the volcanic front of the subduction zone. Slow subMoho mantle $P$ velocities $(7.4-8.0 \mathrm{~km} / \mathrm{sec})$ beneath the peninsula confirm estimates from earlier seismic studies [Fedotov and Slavina, 1968; Kuzin, 1973]. The fastest anomalies reported by Gorbatov et al. [1999], 
as expected, occur within the slab, whose geometry was fixed a priori from seismicity trends.

Slab structure beneath Kamchatka can be probed with guided waves [Abers, 2000] and teleseismic receiver functions [Levin et al., 2002]. Using intermediatefocus slab events, Abers [2000] finds unusual dispersion in $P$ and $S$ waves that can be fit with a thin (1-6 km) layer of low velocities (5-7\% slower than surrounding mantle) at $100-250-\mathrm{km}$ depths at a number of subduction zones in the Pacific. Dry basalt/gabbro and eclogite are too slow and too fast, respectively, to fit the observations, so Abers [2000] argues for metastable hydrated oceanic crust (a blueschist assemblage with lawsonite, chlorite and amphibole) as the main constituent of the low-velocity layer.

Abers [2000] uses seismic station PET (PetropavlovskKamchatsky) to probe the slab waveguide beneath the northern Kuriles and southern Kamchatka. The dipping interfaces that bound this waveguide can be detected beneath PET with teleseismic receiver functions (RFs), which reconstruct $P$-to- $S$ converted waves (also known as $P s$ waves) from the reverberative $P$ coda [Park and Levin, 2000; Levin et al., 2002] (Figure 6). Single-station RF stacks from the SEKS portable seismic deployment detect a similar dipping feature at locations along the east coast of Kamchatka [Levin et al., 2002]. The expression of the slab interface is more prominent on the transverse horizontal component than on the radial, suggesting that $P-S H$ conversion is better developed than $P-S V$ conversion. Such behavior appears common for $P s$ waves that convert within the mantle lithosphere [Bostock, 1997; 1998; Savage, 1998; Levin and Park, 2000; Yuan et al., 2002], and is taken as evidence for anisotropy. Olivine lattice-preferred orientation (LPO) can develop in peridotite rock within a localized shear zone along the downgoing slab. In the subduction zone environment, however, contributions to anisotropy from hydrated serpentinites and blueschists may also be significant.

\subsection{Continental Crust in a Convergent Arc Setting?}

Although it hosts a vigorous chain of arc volcanoes, the crust of Kamchatka has "continental" bulk seismic characteristics. Early studies included $P$ traveltime studies from local earthquakes [Fedotov and Slavina, 1968; Kuzin, 1973] and large-explosion profiles [Utnasin et al., 1975; Balesta et al., 1977; Balesta and Gontovaya, 1985]. More recently, $P$-tomography [Gorbatov et al., 1999], Ps converted phases [Levin et al., 2002] and surface-wave dispersion [Shapiro et $a l ., 2000]$ have been used to constrain crustal properties. Crustal thickness throughout the peninsula lies between $30-40 \mathrm{~km}$ in all estimates. Crustal $P$ velocities are less than $6.7 \mathrm{~km} / \mathrm{s}$ in most estimates, except one region within the Sredinny Range, near the Klyuchevskoy volcano group, where lower-crustal $P$ velocity $(20-30 \mathrm{~km})$ was estimated to be $7.0-7.2$ $\mathrm{km} / \mathrm{sec}$ in refraction surveys [Utnasin et al., 1975]. Evidence for mafic lower crust, argued by Holbrook et al. [1999] to be a defining characteristic of thickened "island-arc" crust, is therefore found only in a limited area.

Simultaneous estimates of crustal $P$ and $S$ velocities are rare in past studies, but comparison of $P$ velocities, e.g. from refraction, and $S$ velocities, e.g. from surface wave dispersion [Shapiro et al., 2000] typically give $V_{P} / V_{S}=1.73-1.76$, suggesting a felsic composition. A felsic $V_{P} / V_{S}$ ratio is also supported by receiver functions, though the influence of anisotropy near the Moho complicates the interpretation of $P s$ converted-wave amplitudes [Levin et al., 2002].

\section{SEISMIC ANISOTROPY AND MANTLE FLOW}

A major target of the "Side Edge of Kamchatka Slab" (SEKS) portable seismological deployment was the interaction of slab descent and asthenospheric flow under the Kamchatka peninsula. Lattice-preferred orientation (LPO) of olivine and orthopyroxene crystals in peridotite is thought to form by ductile flow in the upper mantle [Christensen, 1984; Ribe, 1992; Zhang and Karato, 1995; Zhang et al., 2000]. Olivine is highly anisotropic, and constitutes $40-60 \%$ of the mantle above $420 \mathrm{~km}$ depth. Mantle flow, both ongoing and fossil, is the likely cause of shear-wave birefringence in teleseismic body waves [Vinnik et al., 1984; Silver and Chan, 1991] and Love-to-Rayleigh scattering in long-period surface waves [ $Y u$ and Park, 1994; Kobayashi and Nakanishi, 1998; Levin and Park, 1998b]. In addition, $P s$ converted waves on the transverse-horizontal component of motion can mark sharp anisotropic gradients at depth in the crust and mantle [Bostock, 1997; Savage, 1998; Levin and Park, 1998a]. None of these effects occur if the anisotropy has a near-vertical axis of symmetry, so they are useful indicators of lateral mantle flow. 


\subsection{Regional Mantle Deformation}

Shear-wave birefringence (splitting) parameters for $S K S$ phases in the SEKS deployment fall into two groups [Peyton et al., 2001]. Stations located above the Wadati-Benioff zone (APA, PET, KRO, MIL, TUM) show a trench-parallel fast-polarization direction. Stations away from the slab show other fastpolarization orientations. Trench-normal directions at sites near the Aleutian-Kamchatka junction (ESS, KGB, BNG) rule out a strongly developed trenchparallel mantle fabric beyond the plate boundary corner, as might be expected in the case of strong trench-parallel flow. Trench-normal splitting at ESS, in particular, argues that the slab does not extend downdip beyond its seismogenic zone. This interpretation agrees with regional-scale $P$-wave tomography [Gorbatov et al., 2000] which reports low seismic velocity in the uppermost mantle beneath central Kamchatka. Only a handful of $S K S$ phases exhibit splitting delay times $\delta t>1 \mathrm{~s}$, and these are mostly recorded at the northern stations. Typically, splitting delays of $0.4<\delta t<0.8 \mathrm{~s}$, with formal uncertainties $(1 \sigma)$ of $0.1-0.3 \mathrm{~s}$, define the fast-polarization trends in Figure 7. The splitting delays $\delta t$ of Peyton et al. [2001] are significantly smaller than those of previous studies that used distant stations to make estimates of source-side anisotropy [Kaneshima and Silver, 1992; Fischer and Yang, 1994]. The small number of observations may hide backazimuth and incident-angle variations in splitting values, behavior that could resolve depth variation in anisotropic parameters [Levin et al., 1999].

Two lines of evidence support the hypothesis that trench-parallel $S K S$ splitting at APA, PET, KRO, MIL, and TUM originates below the Wadati-Benioff zone: weak local- $S$ splitting and the deformation of mantle xenoliths (see next section). $S$ waves from earthquakes within the Kamchatka Wadati-Benioff zone traverse the supra-slab mantle wedge and the crust and do not sample anisotropy within and beneath the slab. A group of such events exhibits only weak splitting at stations PET and APA (Figure 8). Peyton et al. [2001] interpret the anisotropy implied by $S K S$ splitting in terms of trench-parallel asthenospheric flow beneath the Pacific plate. As for alternative interpretations of $S K S$ splitting, we doubt that the strain resides entirely in the slab itself, whether due to along-trench extension or fossil fabric. Presentday slab extension would not occur without similar flow in the adjoining asthenosphere. As for fossil slab fabric, an extrapolation of magnetic anomalies beyond the Cretaceous "quiet" magnetic zone predicts that the paleospreading direction within the slab under Kamchatka should be near-normal to the trench. This would imply trench-normal fast polarization above the slab, in conflict with observations.

At stations that lie just beyond the Wadati-Benioff zone, anisotropic fast-polarizations are trench-normal, suggesting strain and/or mantle flow across the plate boundary. Splitting at BNG is likely influenced by the distributed transcurrent deformation along the western Aleutians [Cormier, 1975; Geist and Scholl, 1994]. Splitting at KGB and ESS argues for flow around and beneath the tattered slab edge.

We analysed long-period surface waves recorded at PET for the presence of quasi-Love scattered waves. Events with shallow strike-slip source mechanisms favor large-amplitude Love waves, and best facilitate the observation of mode-converted surfaces waves [Park and Yu, 1993; Yu and Park, 1994; Park, 1997]. Strong lateral gradients of anisotropy near a station cause fundamental-mode Love-to-Rayleigh scattering, which can be observed as anomalous vertical motion in the Love-wave arrival window. We present data from three events in Figure 9. Surface waves in the passband $T>100 \mathrm{sec}$ are most sensitive to the properties of the mantle at depths exceeding $100 \mathrm{~km}$, are largely free of overtone surface waves, and should therefore reflect features of the anisotropic structure below the lithosphere of the Pacific plate.

Events 1 and 2 approach Kamchatka along directions that are $\sim 45^{\circ}$ from the strike of the trench, a geometry that would maximize Love-Rayleigh scattering in the presence of a strong trench-parallel asthenospheric flow gradient [Yu and Park, 1994]. Event 3 approaches PET from the north, and would be sensitive to anisotropy gradients in the back-arc and slabedge regions. Vertical waveforms from events arriving from the NE and SW (events 1 and 2) contain little energy in the Love wave time window. This suggests that neither Love wave encountered strong gradients of trench-parallel seismic anisotropy along their paths. On the other hand, the data for event 3, with northerly backazimuth, contains a characteristic quasi-Love phase on the vertical component in the Love wave time window. The exact location of the anisotropic gradient responsible for this qLove phase may only be determined through waveform modeling, but the modest time separation between the parent Love and the "daughter" qLove phases implies that an anisotropic gradient zone lies within $1000 \mathrm{~km}$ of the receiver. 
Weak or absent Love-to-Rayleigh scattering for events 1 and 2 suggests that the mantle strain field offshore Kamchatka is less disturbed by subduction than at other subduction zones. Quasi-Love waves observed by $Y u$ and Park [1994] in New Zealand had amplitudes $\sim 25 \%$ relative to the incoming Love amplitudes, and could be modelled with a $100-\mathrm{km}$ asthenospheric layer in which $4 \%$ shear anisotropy rotates from trench-normal to trench-parallel $\sim 500 \mathrm{~km}$ seaward of the Kermadec subduction zone. Weak LoveRayleigh scattering offshore southern Kamchatka is consistent with weak $(<1$ s) trench-parallel $S K S$ splitting. By contrast, surface waves arriving at PET from the north show Love-to-Rayleigh scattering in a broad range of periods, including 100 sec. This implies a strong gradient in anisotropy-inducing fabric to the north of PET, which is compatible with the rotation of the fast-polarization direction of $S K S$ phases near the Aleutian-Kamchatka junction.

\subsection{Deformation in the Mantle Wedge and Overlying Crust}

Teleseismic receiver functions ( $\mathrm{RFs}$ ) from the broadband seismological experiment in Kamchatka reveal regional variations in Moho, anisotropy in the supraslab mantle wedge, and, along the eastern coast, $P s$ converted phases from the steeply-dipping slab [Levin et al., 2002]. Although convergent trench-arc boundaries are the most seismically active portions of the global system of tectonic plates, our knowledge of them has significant gaps. Widely-held conceptual models for the structure and dynamics of the descending slab and the supra-slab "mantle wedge" are not fully buttressed by observations. The most common geodynamic model for the supra-slab mantle wedge involves a "corner flow" induced by shear-coupling to the descending slab [e.g. Ida, 1983]. Trench-parallel flow beneath the subducting slab has been proposed for a variety of convergent settings [Alvarez, 1982; Giardini and Woodhouse, 1986] and has found support in measurements of seismic anisotropy [Russo and Silver, 1994; Yu and Park, 1994; Peyton et al., 2001]. Corner flow in the supra-slab mantle wedge would induce a trench-normal anisotropic fast polarization. However, weak shear-wave splitting in the mantle wedge is commonly observed where back-arc spreading is weak [Fischer et al., 1998; Wiemer et al., 1999; Peyton et. al., 2001], and trench-parallel fast polarization has been found in New Zealand [MarsonPidgeon et al., 1999] and the Oregon Cascades [Yuan et al., 2002], where subduction is oblique. A weakly- developed corner flow in the mantle wedge is consistent with the tank experiments of Buttles and Olson [1998].

Levin et al. [2002] analyze both radial- and transversecomponent RFs in bin-averaged epicentral and backazimuth sweeps, in order to detect $P s$ moveout and polarity variations diagnostic of interface depth, interface dip, and anisotropic fabric within the shallow mantle and crust. At some stations the radial $\mathrm{RF}$ is overprinted by near-surface resonances, but anisotropic structure can be inferred from the transverse RF. Using forward modeling to match the observed RFs, Levin et al. [2002] find Moho depth to range between 30 and $40 \mathrm{~km}$ across the peninsula, with a gradational crust-mantle transition beneath some stations along the eastern coast (Figure 10). Anisotropy beneath the Moho is required to fit the transverse RFs at most stations. Anisotropy in the lower crust is required at a minority of stations. By modeling the amplitude and back-azimuth variation of the Ps waveform, Levin et al. [2002] find that a tilted axis of symmetry and 5-10\% anisotropy are typical for the crust and the shallow mantle. The apparent symmetry axes of the anisotropic layers are typically trench-normal, but trench-parallel symmetry axes are found for stations APA and ESS, both at the fringes of the central Kamchatka depression (Figure 11). Transverse RFs from east-coast stations KRO, TUM, ZUP and PET are fit well by two anisotropic mantle layers with trench-normal symmetry axes and opposing tilts. Strong anisotropy in the supra-slab mantle wedge suggests that the mantle "lithosphere" beneath the Kamchatka volcanic arc is actively deforming, strained either by wedge corner-flow at depth or by trenchward suction of crust as the Pacific slab retreats.

The inferred strength of shallow anisotropy in the supra-slab mantle wedge argues that the crust-mantle transition represents an important shear zone in the Kamchatka tectonic system (Figure 12). On face value, this suggests that mantle "lithosphere," in the sense of a semi-rigid peridotite foundation for the 30 40-km continental crust, may not exist in Kamchatka. However, it is possible for the strain that we infer to be fossil, rather than active, deformation.

The trench-normal strike of many inferred anisotropic fast axes is consistent with mantle-wedge flow that is driven by shear coupling to the descending slab. There is a preponderance of trench-normal orientations along the east coast, with the caveat that PET and ZUP are interpreted as trench-normal on the 
basis of similarity in the transverse RF with KRO. Trench-normal fast-polarization axes at UKH, TIG and OSO are less plausibly related to present-day subduction. However, subduction under OSO in northern Kamchatka is not known to be active more recently than $10 \mathrm{Ma}$ [Hochstaedler et al., 1994; Honthaas et al., 1995]. Stations UKH and TIG lie west of the Sredinny Range, and could retain a strain fabric from the Eocene collision of the Olyutorsky terrane [Geist et al., 1994]. If trench-normal sub-Moho mantle fabric under TIG, OSO and UKH is related to subduction processes, the fabric is likely to be fossil, not dynamic, strain. The inferred anisotropic fast axes of stations APA, MIL and ESS, all either within or adjacent to the central depression of Kamchatka, are somewhat variable, and may reflect 3-D complexities in the deformation of the mantle wedge.

Deformed peridotite xenoliths from Avachinsky volcano in Kamchatka contribute to the puzzling data from the supra-slab mantle wedge beneath Kamchatka [Graybill et al., 1999]. All xenoliths examined show evidence of uniaxial compression and olivine LPO with a slow-axis of symmetry, which is unusual among mantle samples. The xenolith strains do not indicate the simple shear expected in standard cornerflow models of mantle wedge deformation, and may arise from localized diapiric flow in the wedge.

\section{VOLCANIC PETROLOGY}

By virtue of its unusual tectonic setting, Kamchatka offers an extreme testing ground for competing arc-volcanism paradigms. Volcanic output is unusually vigorous, igneous fractionation trends have been reported to vary over short distances, and the influence of slab melting is reported in both extrusive rocks and mantle xenoliths. This section summarizes observations from Kamchatka igneous activity that will constrain the seismotectonic scenarios in the Discussion.

Kamchatka hosts one of the most active volcanic arcs on the Earth. Fedotov and Masurenkov [1991] identify 29 distinct active eruptive centers. Erlich and Gorshkov [1979] identify 216 volcanic centers active since the Quaternary, and estimate that the volcanoes of Kamchatka have erupted $0.15 \mathrm{~km}^{3} / \mathrm{yr}$ of eruptive material since $20 \mathrm{ka}$. Kepezhinskas et al. [1997] estimate the output of active Kamchatka volcanoes to comprise $16 \%$ of all land-based volcanic ejecta on Earth. Kersting and Arculus [1994] note that the effusive output of Klyuchevskoy alone (0.022-0.032 $\mathrm{km}^{3} / \mathrm{yr}$ in the past $8-10 \mathrm{kyr}$, according to Fedotov et al. [1987]) is twice that of Fuego, the most active volcano in Guatemala, five times the output of Mount Fuji in Japan, and roughly a quarter of Kiluaea, the most vigorous eruptive center above the Hawaiian hotspot. Klyuchevskoy is not isolated; it is the largest of a cluster of volcanoes that includes Ushkovsky, Bezymianny, and Tobalchik. Bezymianny suffered a 1956 Plinian eruption and lateral blast that covered $60 \mathrm{~km}^{2}$ with a $10-15-\mathrm{m}$ thick layer of broken rubble, and a similar volume $\left(\sim 0.8 \mathrm{~km}^{3}\right)$ of pyroclastic material spread over the adjoining Kamchatka River watershed [Bogoyavlenskaya et al., 1991]. The volcanic output of the Klyuchevskoy group, combined with Sheveluch, the northernmost active volcanic center, accounts for more than half of Kamchatka's eruptive activity [Fedotov and Masurenkov, 1991].

The exceptional volcanic activity in Kamchatka invites a search for exceptional geodynamic and geochemical causes. Seismotectonics and volcanism correlate in suggestive ways. For instance, a large 1996 earthquake $(M=7.0)$ in the Eastern Volcanic Front (EVF) correlated with magma-intrusion tremors near Karimsky volcano and the onset of Strombolian gas eruptions at regular intervals, roughly six per hour [Johnson et al., 1998]. More puzzling is the proximity of the vigorous Sheveluch and Klyuchevskoy volcanic centers in the Central Kamchatka Depression (CKD) to the tattered Pacific slab edge. The chemical composition of igneous activity in the Kamchatka arc can provide clues to this relationship.

\subsection{Igneous Fractionation Trends and the Sources of Arc Magmas}

A venerable paradigm in plate tectonics divides arc volcanism into tholeiitic and calc-alkaline igneous fractionation series, as classified by Miyashiro [1974]. The presence of continental crust is typically correlated with the prevalence of calc-alkaline volcanics, whose origin was connected by Miyashiro [1974] with the progressive depletion of the underlying mantle wedge, and by Plank and Langmuir [1988] with the truncation, by thickened crust, of a "melting column" in the mantle wedge from which partial melt is extracted. The active Kamchatka volcanoes have usually been classified as calc-alkaline [Fedotov and $\mathrm{Ma}$ surenkov, 1991; Volynets, 1994], consistent with their continental-arc locale. In fact, Plank and Langmuir [1988] use Klyuchevskoy to illustrate the influence of ordinary continental crust on $\mathrm{Na}$ and $\mathrm{Ca}$ composition in arc lavas, their main criterion for the "melting 
column" truncation model. However, Tatsumi et al. [1995] interpreted as tholeiitic a suite of Neogene igneous samples from both active and dormant volcanic centers in southern Kamchatka.

Recent estimates of differentiation trends are least simple in the CKD, where Klyuchevskoy erupts largely primitive basalts. Kersting and Arculus [1994] found these to display mixed tholeiitic and calc-alkaline properties, according to standard compositional discriminants. Ozerov et al. [1997] and Ozerov [2000] argue for a calc-alkaline differentiation trend in which high-magnesium basalts, hypothesized to be primary partial melts of hydrated mantle-wedge peridotite, differentiate to form high-aluminum basalts at Klyuchevskoy, and further fractionate to form andesites erupted at Bezymianny. However, Hochstaedler et al. [1996] find clearer patterns in lava composition when other volcanoes in the CKD are analyzed (Ushkovsky, Tobalchik, Sheveluch and the inactive Kharchinsky, Nickolka and Kamen volcanoes). They distinguish the Klyuchevskoy group as tholeiitic, compared with Sheveluch and its inactive neighbor Kharchinsky. By contrast, Hochstaedler et al. [1996] do not find a clear pattern of tholeiitic or calc-alkaline fractionation in selected volcanoes of the EVF.

If one looks beyond the active volcanoes, Kamchatka's igneous compositional trends become more complicated. Predominantly characterized by calcalkaline eruptive products, the Sredinny Range in north and central Kamchatka also hosts examples of Neogene shoshonitic magmatism, high-K alkali basalts that often are associated with intra-plate magmatism [Rotman and Markovskiy, 1975; Volynets, 1994; Kepezhinskas et al., 1997; Winter, 2001]. High$\mathrm{K}$ magnesian basalts, cited as late Miocene-Pliocene by Volynets [1994], are also found behind the Sredinny Range in western Kamchatka.

Kepezhinskas et al. [1997] offer a context for interpretation that minimizes the importance of fractionation trends. They propose a three-component source for Neogene magmatism in Kamchatka: (1) depleted mantle peridotite, (2) a hydrous component derived from the subducting slab, and (3) a slab-melt component, specifically a partial melt of the downgoing oceanic crust. The latter two components supply different patterns of incompatible-element enrichment to melts derived from the depleted-wedge source. A hydrous slab component is present in all arc volcanism, but Kamchatka has peculiarities. Using U/Th-series disequilibrium measurements, Turner et al. [1998] argue that fluid release from the slab occurred more than 150 ky prior to eruption, much longer than similar estimates $(\sim 30 \mathrm{ky})$ for the Aleutians, Marianas, Tonga-Kermadec, and the Lesser Antilles. Another peculiarity involves the contribution of subducted sediments, whose chemical signature commonly influences arc volcanism [Plank and Langmuir, 1998]. The contribution of sediments to Kamchatka volcanics, in contrast to slab-derived fluids, is smaller $(\lesssim 1 \%)$ than in many arcs [Volynets, 1994; Pineau et al., 1999], and may be entirely absent from Klyuchevskoy [Kersting and Arculus, 1995].

\subsection{The Puzzling Signature of Slab Melt: An Indicator of Mantle Enrichment?}

Partial melts of subducted oceanic crust are often cited as the primary source for "adakite" volcanism, commonly marked by high-Mg andesite [Kay, 1978; Drummond and Defant, 1990; Defant and Kepezhinskas, 2001]. A slab-melt component is found to characterize eruptive rocks from Sheveluch and inactive volcanic centers in northern Kamchatka [Hochstaedler et al., 1994; Kepezhinskas et al., 1996; Yogodzinski et al., 2001]. Adakites are most commonly erupted from arc volcanoes above a young, and therefore warm, subducting plate. However, at Sheveluch in Kamchatka and at Adak Island itself in the Aleutians, the subducting plate is old ( $>60 \mathrm{Ma}$ ), and therefore less easy to melt. Yogodzinski et al. [2001] propose that slab melt at Sheveluch and Adak derives from conductive and/or shear heating at the edges of the Kamchatka and central Aleutian slabs, respectively. Their model does not explain, however, the presence of a similar adakite signature in the Neogene volcanoes of northern Kamchatka [Hochstaedler et al., 1994; Kepezhinskas et al., 1997] and the western-Aleutian Komandorsky region [Yogodzinski et al., 1995].

A slab-melt chemical influence need not imply present-day heating of an active subduction zone. Kepezhinskas et al. [1996] note that the "adakite" component of Kamchatka volcanism could derive from a metasomatic enrichment of the mantle wedge by past slab melting. The north Kamchatka volcanics have abundant mantle xenoliths, some of which exhibit a marble-cake intermingling of wedge peridotite with a dacite melt. The major- and trace-element patterns of the dacite component match those predicted for a partial melt of oceanic crust [Kepezhinskas and Defant, 1996; Kepezhinskas et al., 1996]. Adak volcanics also host ultramafic xenoliths, but Myers and Frost [1994] do not report evidence of an infiltrating silicic melt. 
Two-component mantle xenoliths have been identified in other arc-volcanism locales and have been related to infiltrating subduction-related and/or crustal melts [Ertan and Leeman, 1996; Ducea and Saleeby, 1998; Arai et al., 2000]. Mafic pyroxenite veins in upper mantle peridoties have been invoked to explain Os isotope variations in Hawaiian post-erosional volcanism [Lassiter et al., 2000]. Such late-stage hotspot volcanism taps a mantle source that has already undergone the main-stage interval of tholeiitic volcanism [Ribe and Christensen 1999], and so plausibly had been infiltrated (i.e. "enriched") by basaltic melt residuals. In northern Kamchatka, slab-melt metasomatism could have occurred as a byproduct of subducting the young, warm Komandorsky plate in the early Neogene ( $10-25 \mathrm{Ma})$, and become the source of "adakite" chemistry long after subduction had ceased.

The discordant dunite model of Kelemen [1990] returns this section's exposition to its starting point. Kelemen [1990] proposes that an ascending tholeiitic basaltic melt reacts chemically with the peridotite that bounds cracks and pore spaces, exchanging orthopyroxene $(\mathrm{Opx})$ for olivine $(\mathrm{Ol})$ in the wall rock. The mantle develops "discordant" dunite veins in its harzburgite/lherzolite country rock as this interaction proceeds, and the basaltic melt composition evolves along a calc-alkaline trend, enriching more in silica and $\mathrm{Al}_{2} \mathrm{O}_{3}$ than $\mathrm{Fe}$ as it evolves toward andesite and dacite. Kelemen [1990] argues that "slow" ascent of a tholeiitic melt through a hot mantle wedge will generate calc-alkaline magmatism at the surface. A definitive distinction between "slow" and "fast" ascent cannot be made without knowing the kinetics of Ol-Opx replacement reactions; Kelemen [1990] bases his model predictions on equilibrium thermodynamics. If we add a third possibility that some ascending melts solidify as veins in the wedge to enrich the mantle, then Kelemen's conceptual model might be extendable to the adakite problem as well.

The dunite-replacement model for calc-alkaline volcanism can explain variations in eruptive style on a small spatial scale with correlated variations in magmatic flux in either space or time. Small-scale eruptive variability is less easily explained by either wedge depletion [Miyashiro, 1974] or melt-column [Plank and Langmuir, 1988] mechanisms. Within the central Kamchatka depression, Hochstaedler et al. [1996] report the Klyuchevskoy volcanic group as more tholeiitic than Sheveluch. The Klyuchevskoy volcanic group also releases magma at a much faster rate. The vigor of the mantle source of Kluchevskoy basalts is indicated by the absence of a crustal magma chamber beneath the volcano [Balesta et al., 1977; Ozerov et al., 1997]. Seismic sounding suggests that basaltic Klyuchevskoy has a near-direct pipeline to the mantle, in contrast to the neighboring andesitedacite Bezymianny volcano, beneath which a midcrustal magma chamber is detected. If the Kelemen [1990] wallrock interaction model is a significant control on calc-alkaline volcanics, one would expect the eruptive centers with extreme output volumes to favor the tholeiitic trend. CKD volcanism appears to fit this expectation. More comprehensive sampling of Kamchatka volcanics and updated estimates on volcanic productivity are needed, however, to verify the relationship properly.

\section{DISCUSSION: DYNAMICS OF A SLAB EDGE}

Plate-boundary dynamics in Kamchatka are complex, and any explanation must fit data from both present-day and past seismotectonics, plate motions and volcanism. In this discussion, we distinguish three competing hypotheses for Quaternary tectonic processes that govern the present geodynamics of the Aleutian-Kamchatka corner. We also consider how the Cenozoic tectonic evolution of Kamchatka, since the Olyutorsky collision in the mid-Eocene, influenced the transfer of active volcanism from the Sredinny Range to the Eastern Volcanic Front.

Constraints on the timing of events in Cenozoic Kamchatka volcanism and tectonics are far from complete, so our comparison of scenarios can only be provisional. Holocene volcanism has been dated with modern ${ }^{14} \mathrm{C}$ methods [Braitseva et al., 1995], but the application of other modern radiometric methods to older igneous rocks is thusfar limited. Such studies are only beginning [e.g. Honthaas et al., 1995; Garver et al., 2000; Hourigan et al., 2002]. Older syntheses of Kamchatka volcanism and tectonics [e.g., Erlich and Gorshkov, 1979] rely largely on stratigraphic relationships, glaciation indicators and paleomagnetic data.

\subsection{Quaternary Tectonic Scenarios}

We outline here three competing interpretations. We do not claim that other scenarios, not discussed here, would not be possible. In addition, scenario details could be exchanged among the following three hypotheses; they are formulated mainly to focus the interpretation of geologic data. The last hypothesis is the scenario favored by the authors. 
(1) Steady-state geodynamics. The configuration of slab and volcanic centers has undergone little if any Quaternary change. Steady heating of its exposed edge erodes the slab's thermal anomaly, erasing all symptoms of brittle and stiff rheology. Steady melting of subducted crust at the slab edge contributes adakite magma to Sheveluch volcano.

(2) Accelerated slab rollback. The Central Kamchatka Depression (CKD) is an extensional graben associated with slab rollback stresses. The Kamchatka arc is splitting into two arcs, Sredinny and Eastern Volcanic Front (EVF), similar to past rift initiation within the Phillipine plate [Karig et al., 1971; Hussong and Uyeda, 1982], and along the present-day Tonga-Kermadec arc [Wright et al., 1996]. Rifting began in response to an abrupt steepening of the Kamchatka slab, which has brought down a pulse of hydrous sediment to boost volcanism in the CKD (Figure 13). Quaternary volcanism represents a transfer of magma supply from the Sredinny Range to the EVF as the slab steepens. The slab edge is lofted by asthenospheric flow from the Pacific to the North American plate back-arc region. Asthenospheric flow induces frictional heating that erodes the slab edge.

(3) Slab-edge pinchoff. Slab rollback is gradual or absent. Local geodynamic processes have been pulsed by the recent pinchoff of the slab edge via a necking instability [Davies and von Blankenburg, 1995]. The tattered slab edge has lofted in response to the loss of load or to asthenospheric flow, and has induced uplift and pressure-release partial melting in the overlying mantle (Figure 13). CKD magmatism taps depleted mantle-wedge peridotite under the Kluchevskoy group, and adakite-metasomatized mantle under Sheveluch. When the dense slab fragment sank out of the upper mantle, it was replaced by buoyant warm asthenosphere, leading to transient Quaternary uplift and magmatism in the Sredinny Range and farther west.

Steady-state tectonics is the easiest scenario to evaluate. Davaille and Lees [2002] argue that conductive heating at the slab edge is insufficent to cause its inferred erosion, so that convective and mechanical instabilities must be considered. Constraints on the timing of Kamchatka volcanism are incomplete, but all estimates point to the present situation as a transient development. Braitseva et al. [1995] note that most active Kamchatka volcanoes are Holocene in age. Many formed at $7500-7800{ }^{14} \mathrm{C}$ years BP in an intense episode of regional volcanism, including Klyuchevskoy, a 4750-m edifice. Active volcanoes often initiate on the flanks of older calderas; Braitseva et al. [1995] date most of these to be 30-40 ka. For instance, ashes in the Bering Sea dated at $30 \mathrm{ka}$ are interpreted to be from the caldera eruption that preceded the formation of Sheveluch. Radiocarbon dating cannot be used to date volcanic events much older than 50 ka, but Erlich and Gorshkov [1979] argue from other data (e.g. stratigraphic relationships) that the last $\sim 50 \mathrm{kyr}$ has been the most active time interval of Quaternary volcanism.

Quaternary volcanism in the Sredinny Range and farther west, aligned along the extension of the Aleutian island chain, poses a further problem for the steady-state model. Tatsumi et al. [1994; 1995] interpret this volcanism in a steady-state context as a "third volcanic chain" of the Kamchatka arc, supplied by a hydrous peridotite layer entrained downward with the slab - see also Churikova et al. [2001]. Seismic tomography and anisotropy argue that the slab edge is absent beyond the CKD [Gorbatov et al., 1997; 2000; Peyton et al., 2001], so present-day mantle-wedge entrainment is unlikely.

The hypothesis of accelerated slab rollback is motivated largely by (1) an interpretation of the CKD as an extensional graben, developing now while arc magmatism shifts from the Sredinny Range to the EVF, (2) the torsion of the Kamchatka slab edge, perhaps in response to asthenospheric flow around it as it retreats [Kincaid and Olson, 1987; Buttles and Olson, 1998, Hall et al., 2000; Peyton et al., 2001], and (3) a hypothetical geochemical cause for the increase in volcanic output since $50 \mathrm{ka}$. Several observations are at variance with this model, however. Weak development of trench-parallel anisotropy beneath and seaward of the Kamchatka slab (see Section 3) suggests that slab retreat is no more than modest. Although the CKD resembles a graben in a geomorphic sense, it lacks bounding faults that are seismically active. Geptner et al. [1993] describe CKD sediments and their northward extension on Karaginsky Island as thick sequences of clastic alluvium eroded from the neighboring mountains and recent volcanoclastic products from the Klyuchevskoy and Sheveluch centers. No flood basalts in the CKD have been reported, as might be expected in a new rift. Evidence for a recent pulse of subducted material is lacking, because the geochemical signature for sediment influx is weak [Volynets, 1994; Pineau et al., 1999], and the hydrous component appears to be older than in comparable arcs [Turner et al., 1998]. 
The possible mechanisms for the third scenario, slab-pinchoff, include (A) thermal instability leftover from the Hawaii hotspot [Davaille and Lees, 2002]; (B) ductile instability induced by a negatively buoyant cold slab [Davies and von Blankenburg, 1995], perhaps enhanced by the mass heterogeneity of the hotspot track; (C) ductile instability induced by shear concentration at the slab edge associated with rollback flow. The relative merit of these causative mechanisms is not clear, but the likely consequences of slab pinchoff are suggested by several lines of evidence. A negatively-buoyant slab fragment would fall rapidly out of the upper mantle $\left(10^{5}\right.$-yr time scales, using Stokes-flow as a model), and be replaced by upwelling mantle.

This upwelling flow might cause the observed torsion of the residual slab edge, but the loss of load after slab pinchoff could also be a factor. Positive buoyancy in the slab edge may be present if, as Abers [2000] suggests, the oceanic crust has resisted the eclogite phase transformation to depths of $200 \mathrm{~km}$ or more. The time since pinchoff is limited by plate convergence rates and the present-day length of the truncated slab. Assuming a $80 \mathrm{~mm} / \mathrm{yr}$ convergence rate, a $240-\mathrm{km}$ segment of subducted slab edge would limit the pinchoff to be within the last $3 \mathrm{Myr}$. Therefore, rebound subsequent to slab pinchoff can plausibly be related to Quaternary volcanism near the AleutianKamchatka corner.

Above a new "slab window," weak pressure-release partial melting would be expected to produce widely distributed alkalic basalt [Hole et al., 1991]. The slabwindow scenario is broadly consistent with Quaternary volcanism in the Sredinny Range and western Kamchatka opposite the Aleutian corner, where flood basalts are cited by Erlich and Gorshkov [1979] and Fedorov and Shapiro [1998]. Both Volynets [1994] and Fedorov and Shapiro [1998] argue for a rising mantle diapir as the source of inland Quaternary volcanics that are "intraplate" in their trace-element signatures. Fedorov and Shapiro [1998] draw a parallel between the trace-element signature of the Alnei flood basalts of the Kamchatka isthmus and the leucite trachytes of the Roman magmatic province. The Roman analog is suggestive, because central Italy may present a related scenario. In $P$-wave tomography models, the $50-250-\mathrm{km}$ depth range of the upper mantle beneath the central Apennine mountains and the Roman magmatic province lacks a high-velocity anomaly, suggesting that subducted Adriatic lithosphere is missing [Lucente et al., 1999]. Since the high velocity signature of a slab is seen both beneath the northern and southern Apennines in the tomographic models, Wortel and Spakman [2000] conclude that slab detachment has occurred beneath central Italy i.e., under the Roman magmatic province.

Trenchward of the slab window, a lofting of the residual slab near the Aleutian junction would plausibly lead to more intense volcanism. The volcanism would be more arc-like in trace elements, because the chemical composition of the upwelled mantle wedge above the truncated slab would not differ much from a typical depleted arc peridotite. Uplift may generate melts from portions of the wedge that have accumulated the slab-derived hydrous component, similar to that identified by Kepezhinkskas et al. [1997], over a significant time interval. Melt extraction after gradual hydrous infiltration might explain the relatively long ( $>150 \mathrm{kyr})$ fluid residence times indicated by the U-series disequilibrium study of Turner et al. [1998].

Sisson and Bronto [1998] argue that a defining indicator of pressure-release melting in arc systems is a high equilibration temperature between basaltic melt and wedge peridotite, as estimated from mineralcomposition thermometry. The model of Ozerov et al. [1997] for the generation of primary high-magnesian basalts under Klyuchevskoy suggests that partial melt accumulates over 20-50 kbar pressure (corresponding to $60-150 \mathrm{~km}$ depth) at $1350^{\circ}-1400^{\circ} \mathrm{C}$. Ozerov [2000] models the fractionation of high-magnesian basalts to high-alumina basalts to occur over a $\mathrm{P}$ $\mathrm{T}$ range of $1100^{\circ}(7 \mathrm{kbar})$ to $1350^{\circ} \mathrm{C}(19 \mathrm{kbar})$. Kersting and Arculus [1994] report minimum crystalization temperatures for Klyuchevskoy magmas of $1100^{\circ}-1200^{\circ} \mathrm{C}$, depending on which rock sample and mineral-system thermometer are applied. In these estimates, Klyuchevskoy magmatic processes occur at higher temperature than for typical arc-magma systems, though perhaps not as extreme $\left(1320^{\circ} \mathrm{C}\right.$ at $12 \mathrm{kbar}$ ) as the equilibrium P-T conditions Sisson and Bronto [1998] report for water-poor basalts from Galunggung, Indonesia. Finally, a geodynamic, rather than geochemical, impetus for the recent burst of slab-edge volcanism can accommodate the petrologic variations reported between Klyuchevskoy and Sheveluch. The upper mantle beneath Sheveluch may have been metasomatized by slab melt leftover from the Miocene subduction of the young, warm Komandorsky plate, as suggested by mantle xenoliths from past volcanism from the Kamchatka Isthmus [Kepezhinskas et al., 1996]. This secondary melting mechanism, and not the direct melting of the Pacific 
lithosphere edge, may explain Sheveluch's adakite chemical signature, and link its eruptive chemistry with that of Neogene volcanoes of Northern Kamchatka.

A major distinction between Quaternary hypotheses (2) and (3) is predicted regional uplift. Abrupt slab rollback should induce subsidence in the backarc region, at least until asthenospheric mantle manages to flow from the Pacific to the North American side. The loss of a slab edge would lead to a gravity low and asthenospheric upwelling to fill the gap. The tattered slab edge might be lofted by upwelling flow, or else by loss of the downdip load if its crust is metastably buoyant. Both pinchoff scenarios predict transient uplift in central Kamchatka. Though the detailed sequence of volcanism and uplift are as yet unknown, such uplift might explain why the Kamchatka river does not flow to the ocean along the entire length of the low-lying central Kamchatka depression to its coastline near Cape Ozernoy on the Bering Sea, but rather turns toward the Aleutian-Kamchatka corner northeast of Klyuchevskoy. Rivers will change course in response to vertical tectonic movements [e.g. Mather, 2000]. Erlich and Gorshkov [1979] interpret the CKD as a shallow marine basin as late as the lower Pliocene $(\sim 3-6 \mathrm{Ma})$, so it is likely that the Kamchatka river would have flowed all the way to Cape Ozernoy unless the CKD uplifted unevenly. The slab-pinchoff hypothesis predicts that transient uplift of central Kamchatka would have deflected the course of the Kamchatka river towards the Pacific coastline.

The Kamchatka river now reaches the ocean after penetrating the Kumroch Range in a narrow valley. The river's course most likely predated the Kumroch topography, and cut through the mountains as they rose. The timing of Kumroch uplift is not tightly constrained; Levashova et al. [1997] report "PlioceneQuaternary volcanic and continental deposits" on it. The Kumroch Range is plausibly coeval with the thrusting of the terrane collision that formed Cape Kamchatka, but this event is also not yet dated with confidence. Hypothesis (3) therefore makes specific predictions regarding the sequence of volcanic and tectonic events in central Kamchatka. These predictions should be testable with future field studies of the area.

\subsection{Cenozoic Tectonics Since the Olyutorsky Collision}

The scarcity of radioisotope ages for Kamchatka rocks makes reconstruction of its Cenozoic volcanic history especially difficult. The same can be said of the Cenozoic tectonic history of the peninsula, as the accretion of the Cape terranes is not dated securely. Many authors suggest a causal relation between the accretion of the Cape terranes to southern Kamchatka and the eastward shift of volcanism from the southern Sredinny Range to the Eastern Volcanic Front. Because the constraining data are thusfar few in number, proposed models differ significantly among different researchers. In this subsection, we suggest a range of scenarios that have been proposed by, or can be extrapolated from, recent research in the region. As with the Quaternary tectonic scenarios, we do not claim our discussion to be conclusive or comprehensive, but rather to highlight future research opportunities in the Kamchatka region.

Two end-member scenarios for the formation of the Aleutian-Kamchatka junction, and the isolation of the Komandorsky Basin from the Pacific plate, can be recognized in recent research. The scenarios differ in how the Cape terranes accreted to southern Kamchatka. In one case, the junction formed in the latest Cenozoic with the accretion of Cape Kamchatka in its present position at $56^{\circ} \mathrm{N}$. In the alternate case, the junction formed somewhat earlier and farther south, with the accretion of Cape Shipunsky, and migrated northeast as a triple junction between the North American, Pacific and Komandorsky plates.

The accretion of Cape Shipunsky and Cape Kronotsky in many reconstructions of Cenozoic Kamchatka tectonics occurs with the closure of one or more small ocean basins [Zonenshain et al., 1990; Zinkevich and Tsukanov, 1992; Shapiro et al., 1997; Konstantinovskaya, 1999; Levashova et al., 2000; Konstantinovskaia, 2001]. In this interpretation, the island-arc affinity of, say, Cape Kronotsky implies the existence of a Kronotsky island arc in the open Cretaceous-Paleocene ocean (Figure 14), followed by translation of this arc from middle paleomagnetic latitudes to its current location on the Kamchatka coastline $\left(\sim 55^{\circ} \mathrm{N}\right)$. Levashova et al. [2000] report paleolatitudes in the range $38^{\circ}-45^{\circ} \mathrm{N}$ for the Kronotsky terrane. Note that the Kamchatka peninsula, as part of the North American plate, is inferred to have migrated southward a roughly equal interval of latitude during this time. Although paleomagnetism of Cape Kronotsky and Cape Kamchatka has seen greater study, the island-arc affinity of the more southerly Cape Shipunsky is also recognized, so that multiple small island arcs are commonly hypothesized in plate reconstructions [e.g., Seliverstov, 1998]. The 
demise of an ocean basin that formerly lay between Kamchatka and the accreted arcs has commonly been cited for the late-Cenozoic jump in volcanism from the Sredinny Range to the EVF.

Alternatively, in some early reconstructions [ Jurdy and Gordon, 1984; Gordon and Jurdy, 1986; Bazhenov et al., 1991] the Pacific-North American plate boundary was placed near the southern tip of Kamchatka in the middle Eocene. However, the contemporary gap in paleolatitude between Kamchatka and the Cape terranes [Levashova et al., 2000] argues for a significant gap at the time of the Olyutorsky collision. Such a gap between Kamchatka and the future Aleutian arc is a feature of more recent tectonic reconstructions [Seliverstov, 1998; Nokleberg et al., 2001]. These new reconstructions, however, do not rule out the formation of the Aleutian-Kamchatka junction at a southern position at a later time. Rather than residing on separate island-arc segments, the three Cape terranes could have formed as part of what we now recognize as the Aleutian arc. If so, they could have been thrust singly onto the east Kamchatka margin as the triple junction moved north (Figure 15). In this "caulking-gun" scenario, the former islands accreted to Kamchatka as the Komandorsky triple junction migrated northeast from an initial location near the southern tip of Kamchatka, emplaced by transcurrent shear along the Pacific-North American plate boundary. Such shear is now distributed across the western Aleutian arc [Ekstrom and Engdahl, 1989; McCaffrey, 1996]. Ave Lallement and Oldow [2000] argue that the island chain experiences extensional thinning along its length, consistent with the breakup of the Aleutian arc into tectonic blocks of a few volcanic centers each [Geist and Scholl, 1994; Myers and Frost, 1994]. The successive accretion of individual islands along the Kamchatka coast would be facilitated by alongarc extension.

A conclusive evaluation of the above models is not possible at present. However, we favor the caulkinggun model, in which the Cape terranes accrete as a byproduct of triple-junction migration, over the "multiple arc" model, in which separate accretion of the Shipunsky and Kronotsky capes involves the closure of one or more small ocean basins. Our choice partly stems from a bias toward a tectonic model with fewer moving parts. Multiple island arcs imply the formation and maintenance of short $(100-200 \mathrm{~km})$ subduction zones in the open ocean (Figure 14). Although the length scale of subducting lithospheric fragments is observed to be short in convergence zones that in- volve continental lithosphere [Wortel and Spakman, 2000], ocean-ocean subduction zones are more commonly $500-\mathrm{km}$ or more in length. Also, each closure of an ocean basin would have left a relict slab under the south Sredinny Range. No evidence for this has been reported, though a future interpretation of late-Cenozoic volcanism in southern Kamchatka may suggest slab rollback and/or detachment.

Triple-junction migration predicts an unusual mechanism for the transfer of mid-Cenozoic island-arc volcanism from the Sredinny range to the EVF. The relict Miocene spreading center in the present-day Komandorsky Basin suggests that the oceanic lithosphere of the late-Cenozoic Komandorsky plate was young and buoyant. After the accretion of Cape Shipunsky has isolated the Komandorsky from the Pacific plate, the triple-junction migration scenario has the young, buoyant Komandorsky plate subduct at a shallow angle and generate arc volcanism in the inland Sredinny Range, forming a near-continuous arc from near Cape Shipunsky to the Koryak highlands. Pacific plate subduction south of the Aleutians would involve older denser lithosphere, subducting at a steep dip. Therefore a slab tear would likely develop at the Aleutian-Kamchatka triple junction and propagate northeast with it in the late Cenozoic. As the triple junction migrated up the Kamchatka margin, the Eastern Volcanic Front would develop trenchward of the Sredinny Range, shifted both by the slab tear and any accreted Aleutian material. Due to post-collisional igneous activity and/or the effects of transient "slab windows," volcanism in the Sredinny Range would persist after the triple junction had passed, but with changes in style and chemical signature.

If the Aleutian-Kamchatka triple junction migrated, when did it start and stop moving? The emplacement of Cape Shipunsky likely bounds the starting time, and the cessation of Komandorsky subduction bounds the stopping time. The collision time of Cape Shipunsky is currently unknown. Hochstaedler et al. [1994] and Honthaas et al. [1995] report "islandarc" magmatism in Northern Kamchatka as late as $15 \mathrm{Ma}$ and $10 \mathrm{Ma}$, respectively, and "adakitic" magmatism as early as 6-8 Ma. Adakitic magmatism does not preclude the continued subduction of the young Komandorsky lithosphere, but indicates that convergence has changed character.

An important timing constraint may be found in the revised history of Pacific absolute plate motions (APM) by Wessel and Kroenke [1997; 2000], who of- 
fer multiple lines of evidence for a significant change in Pacific plate motion during the 2-6 Ma interval in the hotspot reference frame. Induced by the stalled subduction of the Ontong Java Plateau, the inferred change in local Pacific plate velocity is largest in the southern hemisphere. Nevertheless, the Pacific plate APM near the Aleutian-Kamchatka junction is predicted by Wessel and Kroenke [2000] to increase from $\sim 70$ to $130 \mathrm{~mm} / \mathrm{yr}$, and to deflect $\sim 15^{\circ}$ counterclockwise. The Pacific APM change does not determine changes in relative plate motions uniquely, but the magnitude and sense of the change is instructive. If we assume that the present-day Pacific motion of Wessel and Kroenke [1997] is parallel to the western Aleutians, the Miocene-Pliocene shift in their APM model predicts $\sim 18 \mathrm{~mm} / \mathrm{yr}$ convergence prior to the shift. Because evidence for mid-Cenozoic subduction under the western Aleutians is scarce [Yogodzinski et al., 1993], this "convergence" can be interpreted as northeast migration of the Komandorsky triple junction, in agreement with the caulking-gun model. If $18 \mathrm{~mm} / \mathrm{yr}$ is interpreted as a northeast migration velocity, with plate convergence transferred to the Komandorsky-North America convergent margin, the $400 \mathrm{~km}$ between Cape Shipunsky and Cape Kamchatka implies $\sim 22 \mathrm{Myr}$ of plate motion. The true Pacific-Komandorsky motion is surely somewhat different, but the rough velocity estimate supports the feasibility of the triple-junction migration hypothesis.

If the Wessel and Kroenke [2000] APM shift caused the cessation of Kommandorsky subduction, then subduction persisted at least until $6 \mathrm{Ma}$, and perhaps as recently as $2 \mathrm{Ma}$. The latter date raises the possibility that the cessation of Komandorsky subduction and the loss of the Pacific slab edge manifest a single regional tectonic event. This possibility deserves attention, even though it is an extreme interpretation of the scant geological data now available.

\section{SUMMARY}

Present-day Kamchatka plate dynamics involve the subduction of a finite slab, terminated at the Aleutian-Kamchatka junction. The edge of the subducting slab is tattered and torsioned into a dip shallower than that of the main Kamchatka slab. Above the torsioned slab edge, active volcanic centers trend inland along the $100-\mathrm{km}$ depth contour of the WadatiBenioff zone, stepping from the Eastern Volcanic Front (EVF) into the Central Kamchatka Depression (CKD). Here the volcanic arc terminates in a clus- ter of unusually vigorous volcanoes, the Klyuchevskoy group and Sheveluch.

The pattern of earthquake activity and estimates of seismic anisotropy from $S K S$ splitting and LoveRayleigh scattering suggest that mantle fabric transitions from a weakly developed trench-parallel fastaxis orientation beneath the seismogenic slab to trenchnormal near its northeast edge. Comparison with other arcs, particularly Tonga-Kermadec, suggests that slab rollback beneath Kamchatka is weak. In the supra-slab mantle wedge, path-integrated anisotropy from local $S$ splitting is weak, but anisotropic gradients in the upper $50 \mathrm{~km}$ of the lithosphere induce strong conversions of teleseismic $P$ - to $S$-polarized scattered waves. Shallow near-Moho anisotropy appears to have a trench-normal symmetry axis under the EVF, but stations in or adjacent to the CKD have more variable symmetry-axis orientations. This suggests that any shear-coupled corner flow in the Kamchatka wedge is limited to the immediate vicinity of the trench-volcano arc.

Kamchatka plate dynamics have been transient on several time scales. Upper-mantle tomography and the ratio of seismic-moment release to inferred plate motion suggest that the downgoing Pacific lithosphere is anchored to the lower mantle via slab penetration and strongly coupled to the overlying North American plate, while the adjoining Kurile and Aleutian trenches have suffered rollback at intervals over the past 100 My. Rifting of the Komandorsky Basin and its subduction under northern Kamchatka ceased sometime since $10 \mathrm{Ma}$, perhaps in response to a change in absolute Pacific plate motion starting at $6 \mathrm{Ma}$. Several lines of evidence suggest that the slab edge has suffered the loss of downdip material since 2 $\mathrm{Ma}$, either from thermo-convective erosion or a necking instability. Evidence for Quaternary uplift and enhanced volcanism near the Aleutian-Kamchatka junction are consistent with the recent catastrophic loss of a slab fragment. The vigorous volcanoes of the CKD are quite young $(<50 \mathrm{ka})$. The course of the Kamchatka River may have been deflected towards the Pacific coast away from the CKD by vertical tectonic movements. Alkalic Quaternary volcanism in the Kamchatka interior may be related to broad "slab-window" asthenospheric upwelling induced by loss of the slab edge. The shared vigor and diverse geochemistry of the neighboring Klyuchevskoy and Sheveluch volcanoes in the CKD suggests a common geodynamic factor (pressure-release melting caused by recent lofting of the tattered slab edge) oper- 
ating on geochemically diverse mantle sources (depleted wedge peridotite under Klyuchevskoy, adakitemetasomatized peridotite under Sheveluch).

The evolution of tectonic and volcanic activity in Kamchatka since the mid-Eocene can be understood in terms of a gradual shifting of arc volcanism from the inland Sredinny Range to the coastal EVF, coeval with the accretion of three "Cape terranes" along the eastern coast. We propose a reconstruction in which the Cape terranes (Shipunsky, Kronotsky, Kamchatka) were originally islands of the western Aleutians, and collided edgewise with Kamchatka some time after the accretion of the Olyutorsky terrane to the Eurasian margin in the mid-Eocene. The islands accreted to Kamchatka in a "caulking-gun" process as the North American/Pacific/Komandorsky triple junction migrated northeast. Since the Komandorsky and Pacific lithospheres are young and old, respectively, in this scenario, the passage of the triple junction would also induce a progressive change from a shallow-dipping Wadati-Benioff zone to a steeply dipping zone, facilitating the transfer of active volcanism from the Sredinny Range to the EVF.

Acknowledgments. This research was supported by the NSF grants EAR-9614639 (data collection and archiving) and EAR-9805206 (seismic data analysis), EAR9418989 and OPP-9911925 (geological field work). The resources of the Kamchatka Experimental Methodical Seismic Department (V. Chebrov, O. Dontsov, E. Tokarev, V. Stepanov, V. Sinitsyn, N. Titkov, I. Semchenko) and support from the Institute of Volcanology (V. Gorelchik, A. Osipenko, L. Osipenko) were critical to the success of the SEKS field campaign. Support from the IRIS PASSCAL staff (Matthew Fouch, Paul Friberg, Noel Barstow, Doug Johnson, Mary Templeton) and from Rick Benson at the IRIS DMC is acknowledged with gratitude. We used GMT software [Wessel and Smith, 1991] to prepare figures. Kristina Rodriguez provided a file of volcano locations. Comments from Jeff Rahl on the manuscript were helpful. Jeffrey Freymuller and two anonymous colleagues gave the initial manuscript thoughtful reviews.

\section{References}

Abers, G. A., Hydrated subducted crust at 100-250 km depth, Earth Planet. Sci. Lett., 176, 323-330, 2000.

Ague, J. J., J. Park, and D. M. Rye, Regional metamorphic dehydration and seismic hazard, Geophys. Res. Lett., 25, 4221-4224, 1998.

Alekseyev, E. S., Geodynamics of the ocean-continent transition zone as exemplified by the late MesozoicCenozoic history of the southern area of the Koryak highlands, Geotectonics, 21, 373-382, 1987.

Alvarez, W., Geological evidence for the geographical pattern of mantle return flow and the driving mechanism of plate tectonics, J. Geophys. Res., 87, 6697-6710, 1982.

Arai, S., H. Hirai, and K. Uto, Mantle peridotite xenoliths from the Southwest Japan arc: A model for the sub-arc upper mantle structure and composition of the Western Pacific rim, J. Min. Petrol. Sci., 95, 9-23, 2000.

Ave Lallement, H. G., and J. S. Oldow, Active displacement partitioning and arc-parallel extension of the Aleutian volcanic arc based on Global Positioning System geodesy and kinematic analysis, Geology, 28, 739$742,2000$.

Balesta, S. T., A. I. Farberov, V. S. Smirnov, A. A. Tarakanovsky, and M. I. Zubin, Deep crustal structure of the Kamchatkan volcanic regions, Bull. Volcanol., $40260-266,1977$.

Balesta, S. T. and Gontovaya, L. I., Crustal structures in the Kamchatkan segment of the Pacific transition zone, J. Geodyn., 3, 245-257, 1985.

Baranov, B. V., N. I. Seliverstov, A. V. Muravev, and E. L. Muzurov, The Komandorsky Basin as a product of spreading behind a transform plate boundary, Tectonophys., 199, 237-269, 1991.

Bazhenov, M. L., V. S. Burtman, O. A. Krezhovskikh, and M. N. Shapiro, Paleotectonic reconstruction of the Aleutian Arc-Kamchatka convergence zone, Geotectonics, 25, 244-256, 1991.

Bogatikov, O. A., V. I. Kovalenko, E. V. Sharkov, and V. V. Yarmolyuk, Magmatism in the context of presentday tectonic settings, in Magmatism and Geodynamics: Terrestrial Magmatism Throughout the Earth's History, edited by O. A. Bogatikov, Gordon and Breach, Amsterdam, Netherlands, 2000.

Bogdanov, N. A., S. M. Til'man, and V. D. Chekhovich, Late Cretaceous-Cenozoic history of the Koryak-Kamchatka region and the Commander Basin of the Bering Sea, Int. Geol. Rev., 32, 1185-1201, 1990.

Bogoyavlenskaya, G. Ye., O. A. Braitseva, I. V. Melekestsev, A. P. Maksimov, and B. V. Ivanov, Bezymianny volcano, in Active Volcanoes of Kamchatka, edited by S. A. Fedotov, and Yu. P. Masurenkov, Nauka, Moscow, Russia, 1991.

Boldyrev, S. A., Distribution of elastic wave velocities at the juncture of the Kurile-Kamchatka and Aleutian Island arcs, Trans. AN SSSR, Earth. Sci., 215, 1-6, 1974. 
Bostock, M. G., Anisotropic upper-mantle stratigraphy and architecture of the Slave craton, Nature, 390, 393395, 1997.

Bostock, M. G., Mantle stratigraphy and the evolution of the Slave province, J. Geophys. Res., 103, 21183-21200, 1998.

Boyd, T. M., and K. C. Creager, The geometry of Aleutian subduction: Three-dimensional seismic imaging, J. Geophys. Res., 96, 2267-2291, 1991.

Braitseva, O. A., I. V. Melekestsev, V. V. Ponomareva, and L. D. Sulerzhitsky, Ages of calderas, large explosive craters and active volcanoes in the Kuril-Kamchatka region, Russia, Bull. Volcanol., 57, 383-402, 1995.

Burgmann, R., M. G. Kogan, V. E. Levin, C. H. Scholz, R. W. King, and G. M. Steblov, Rapid aseismic moment release following the 5 December, 1997 Kronotsky, Kamchatka, earthquake, Geophys. Res. Lett., 28, 1331-1334, 2001.

Buttles, J. and P. Olson, A laboratory model of subduction zone anisotropy, Earth Planet. Sci. Lett., 164, 245$262,1998$.

Chemenda, A. I., M. Mattauer, J. Malavielle, and A. N. Bokun, A mechanism for syncollisional rock exhumation and associated normal faulting: Results from physical modelling, Earth Planet. Sci. Lett., 132, 225-232, 1995.

Christensen, N. I., The magnitude, symmetry and origin of upper mantle anisotropy based on fabric analyses of ultramafic tectonites, Geophys. J. R. Astron. Soc., 76, 89-111, 1984.

Christova, C., Depth distribution of stresses in the Kamchatka Wadati-Benioff zone inferred by inversion of earthquake focal mechanisms, J. Geodyn., 31, 355-372, 2001.

Churikova, T., F. Dorendorf, and G. Worner, Sources and fluids in the mantle wedge below Kamchatka, evidence from across-arc geochemical variation, J. Petrology, 42, 1567-1593, 2001.

Cook, D. B., K. Fujita, and C. A. McMullen, Presentday plate interactions in northeast Asia: North American, Eurasia, and Okhotsk plates, J. Geodyn., 6, 33-51, 1986.

Cormier, V. F., Tectonics near the junction of the Aleutian and Kuril-Kamchatka arcs and a mechanism for middle Tertiary magmatism in the Kamchatka basin, Geol. Soc. Amer. Bull., 86, 443-453, 1975.

Creager, K. C., and T. M. Boyd, The geometry of Aleutian subduction: Three-dimensional kinematic flow model, J. Geophys. Res., 96, 2293-2307, 1991.

Davaille, A., and J. M. Lees, Thermal modelling of subducted plates: Tear and hot spot at the Kamchatka corner, Geophys. Res. Lett., submitted 2002.

Davies, J. H., and F. von Blankenburg, Slab breakoff: A model of lithosphere detachment and its test in the magmatism and deformation of collisional orogens, Earth Planet. Sci. Lett., 129, 85-102, 1995.
Defant, M. J., and P. Kepezhinskas, Evidence suggests slab melting in arc magmas, Eos Trans. AGU, 82, 6569, 2001.

DeMets, C., R. G. Gordon, D. F. Argus and S. Stein, Current plate motions, Geophys. J. Int., 101, 425-478, 1990.

DeMets, C., Oblique convergence and deformation along the Kuril and Japan trenches, J. Geophys. Res., 97, 17615-17625, 1992a.

DeMets, C., A test of present-day plate geometries for northeast Asia and Japan, J. Geophys. Res., 97, 1762717635, 1992b.

Dewey, J. F., Episodicity, sequence, and style at convergent plate boundaries, in The Continental Crust and its Mineral Deposits, edited by D. W. Strangway, Geol. Assoc. Can., Spec. Pap., 20, pp. 553-573, 1980.

Drummond, M. S., and M. J. Defant, A model for trondhjemite-tonalite-dacite genesis and crustal growth via slab melting: Archean to Modern comparisons, J. Geophys. Res., 95, 21503-21521, 1990.

Ducea, M., and J. Saleeby, Crustal recycling beneath continental arcs: silica-rich glass inclusions in ultramafic xenoliths from the Sierra Nevada, California, Earth Planet. Sci. Lett., 156, 101-116, 1998.

Ekstrom, G., and E. R. Engdahl, Earthquake source parameters and stress distribution in the Adak Island region of the central Aleutian Islands, Alaska, J. Geophys. Res., 94, 15499-15519, 1989.

Engdahl, E. R., R. D. van der Hilst, and R. P. Buland, Global teleseismic earthquake relocation with improved travel times and procedures for depth determination, Bull. Seismol. Soc. Am., 88, 722-743, 1998.

Erlich, E. N., and G. S. Gorshkov (Eds.), Quaternary volcanism and tectonics in Kamchatka, Bull. Volcanol., 42, 1-298, 1979.

Ertan, I. E., and W. P. Leeman, Metasomatism of Cascades subarc mantle: Evidence from a rare phlogopite orthopyroxenite xenolith, Geology, 24, 451-454, 1996.

Faccenna, C., M. Mattei, R. Funiciello, and L. Jolivet, Styles of back-arc extension in the central Mediterranean, Terra Nova, 9, 126-130, 1997.

Fedorov, P. I., and M. N. Shapiro, Neogene volcanics of the Kamchatka isthmus and geodynamics of the AleutianKamchatka junction, Geotectonics, 32, 122-137, 1998.

Fedotov S. A., I. P. Kuzin and M. F. Bobkov, Detailed seismological studies in Kamchatka in 1961-63 (in Russian), Izv. AN USSR, Geophysics Series, 9, 1964.

Fedotov, S. A., and Slavina, L. B., Estimation of longitudinal wave velocities in the upper mantle beneath north-western part of the Pacific and Kamchatka (in Russian), Izv. AN SSSR Fizika Zemli, 2, 8-31, 1968.

Fedotov, S. A., A. P. Khrenov, and N. A. Jarinov, Klyuchevskoy volcano, its activity in 1932-1986 and possible development, Volcanol. Seismol., 4, 3-16, 1987.

Fedotov, S. A., and Yu. P. Masurenkov (Eds.), Active Volcanoes of Kamchatka, Nauka, Moscow, Russia, 1991. 
Fischer, K. M. and X. Yang, Anisotropy in Kuril-Kamchatka subduction zone structure, Geophys. Res. Lett., 21, 58, 1994.

Fischer, K. M., M. Fouch, D. Wiens and M. Boettcher, Anisotropy and flow in Pacific subduction zone backarcs, Pur. App. Geoph., 151, 463-475, 1998.

Fujita, K., and J. T. Newberry, Accretionary terranes and tectonic evolution of northeastern Siberia, in Accretion Tectonics in the Circum-Pacific Regions, edited by M. Hashimoto and S. Uyeda, pp. 43-57, Terra Scientific, Tokyo, 1983.

Fujita, K., D. B. Cook, H. Hasegawa, D. Forsyth and R. Wetmiller, Seismicity and focal mechanisms of the Arctic region and the North American plate boundary in Asia, in The Arctic Ocean Region (The Geology of North America), edited by A. Grantz, L. Johnson and J. F. Sweeney, pp. 79-100, Geological Society of America, Boulder, 1990.

Gaedicke, C. B. Baranov, N. Seliverstov, A. Alexeiev, N. Tsukanov, and R. Freitag, Structure of an active arc-continent collision area: The Aleutian-Kamchatka junction, Tectonophys., 325, 63-85, 2000.

Garver, J. I., A. V. Soloviev, M. E. Bullen, and M. T. Brandon, Towards a more complete record of magmatism and exhumation in continental arcs using detrital fission track thermochronometry, Phys. Chem. Earth, Part A, 25, 565-570, 2000.

Geist, E. L. and D. W. Scholl, Application of continuum models to deformation of the Aleutian island arc, $J$. Geophys. Res., 97, 4953-4967, 1992.

Geist, E. L. and D. W. Scholl, Large-scale deformation related to the collision of the Aleutian arc with Kamchatka, Tectonics, 13, 538-560, 1994.

Geist, E. L., T. L. Vallier, and D. W. Scholl, Origin, transport, and emplacement of an exotic island-arc terrane exposed in eastern Kamchatka, Russia, GSA Bull., 106, 1182-1194, 1994.

Geptner, A. R., N. P. Kuralenko, and T. S. Kraevaya, Volcanism Impact on Sedimentation on Land and Shelf of Kamchatka, 129 pp., Russian Academy of Sciences, Moscow, 1993.

Giardini, D. and J. H. Woodhouse, Horizontal shear flow in the mantle beneath Tonga arc, Nature, 319, 551-555, 1986.

Gnibidenko, H. S., and I. I. Khvedchuk, The tectonics of the Okhotsk Sea, Mar. Geol., 50, 155-198, 1982.

Gnibidenko, H. S., T. W. C. Hilde, E. V. Gretskaya, and A. A. Andreyev, Kuril (South Okhotsk) backarc basin, in Backarc Basins: Tectonics and Magmatism, edited by B. Taylor, pp. 421-449, Plenum Press, New York, 1995.

Gorbatov, A., V. Kostaglodov, G. Suarez, and E. Gordeev, Seismicity and structure of the Kamchatka subduction zone, J. Geophys. Res., 102, 17883-17898, 1997.

Gorbatov, A., J. Dominguez, G. Suarez, V. Kostoglodov, D. Zhao and E. Gordeev, Tomographic imaging of the $P$-wave velocity structure beneath the Kamchatka peninsula, Geophys. J. Int., 137, 269-279, 1999.

Gorbatov, A., A. Widiyantoro, Y. Fukao, and E. Gordeev, Signature of remnant slabs in the North Pacific from $P$ wave tomography, Geophys. J. Int., 142, 27-36, 2000.

Gordon, R. G., and D. M. Jurdy, Cenozoic global plate motions, J. Geophys. Res., 91, 12389-12406, 1986.

Graybill, J., M. T. Brandon, and P. K. Kepezhinskas, Olivine lattice-preferred orientation in xenoliths from the mantle wedge beneath the Southern Kamchatka volcanic arc (abstract), Eos Trans. AGU, 80, F926, 1999.

Hall, C. E., K. M. Fischer, E. M. Parmentier, and D. K. Blackman, The influence of plate motions on threedimensional back arc mantle flow and shear wave splitting, J. Geophys. Res., 105, 28009-28033, 2000.

Hochstaedler, A. G., P. K. Kepezhinskas, M. J. Defant, M. S. Drummond, and H. Bellon, On the tectonic significance of arc volcanism in northern Kamchatka, $J$. Geology, 102, 639-654, 1994.

Hochstaedler, A. G., P. Kepezhinskas, M. J. Defant, M. S. Drummond, and A. Koloskov, Insights into the volcanic arc mantle wedge from magnesian lavas from the Kamchatkan arc, J. Geophys. Res., 101, 697-712, 1996.

Holbrook, W. S., D. Lizarralde, S. McGeary, N. Bangs and J. Diebold, Structure and composition of the Aleutian island arc and implications for continental crustal growth. Geology, 27, 31-34. 1999.

Hole, M. J., G. Rogers, A. D. Saunders, and M. Storey, Relation between alkalic volcanism and slab window formation, Geology, 19, 657-660, 1991.

Honthaas, C., H. Bellon, P. K. Kepezhinskas, and R. C. Maury, New ${ }^{40} \mathrm{~K}-{ }^{40}$ Ar dates for the Cretaceous-Quaternary magmatism of Northern Kamchatka (Russia), $C$. R. Acad. Sci. Paris, Serie II, 320, 197-204, 1995.

Hourigan, J., M. T. Brandon, J. Garver, A. Soloviev, P. Reiners, and G. Bondarenko, Significance of new U-Pb ages for the tectonic evolution of Kamchatka, Geology, submitted 2002.

Hussong, D. M., and S. Uyeda, Tectonic processes and the history of the Mariana arc: A synthesis of the results of DSDP Leg 60, Init. Rep. DSDP, 60, 909-929, 1982.

Ida, Y., Convection in the mantle wedge above the slab and tectonic processes in subduction zones, J. Geophys. Res., 88, 7449-7456, 1983.

Imaev, V. S., L. P. Imaeva, B. M. Koz'min, L. V. Gunbina, K. G. Mackey, and K. Fujita, Seismicity and presentday boundaries of plates and blocks in northeast Asia, Geotectonics, 34, 294-301, 2000.

Johnson, J. B., J. M. Lees and E. Gordeev, Degassing explosions at Karimsky Volcano, Kamchatka, Geophys. Res. Letts., 25, 3999-4002, 1998.

Jolivet, L., America-Eurasia plate boundary in eastern Asia and the opening of marginal basins, Earth Planet. Sci. Lett., 81, 282-288, 1987. 
Jurdy, D. M., Relative plate motions and the formation of marginal basins, J. Geophys. Res., 84, 6796-6802, 1979.

Jurdy, D. M., and M. Stefanick, Flow models for back-arc spreading, Tectonophys., 99, 191-206, 1983.

Jurdy, D. M., and R. G. Gordon, Global plate motion relative to the hot spots 64 to $56 \mathrm{Ma}, J$. Geophys. Res., 89, 9927-9936, 1984.

Kaneshima, S., and P. G. Silver, A search for source-side anisotropy, Geophys. Res. Lett., 19, 1049-1052, 1992.

Karig, D. E., Structural history of the Mariana island arc system, Geol. Soc Am. Bull., 82, 323-344, 1971.

Kay, R. W., Aleutian magnesian andesites: Melts from subducted Pacific Ocean crust, J. Volcanol. Geotherm. Res., 4, 117-132, 1978.

Kelemen, P. B., Reaction between ultramafic rock and fractionating basaltic magma I. Phase relations, the origin of calc-alkaline magma series, and the formation of discordant dunite, J. Petrology, 31, 51-98, 1990.

Kepezhinskas, P. K., and M. J. Defant, Contrasting styles of mantle metasomatism above subduction zones: Constraints from ultramafic xenoliths in Kamchatka, in Subduction: Top to Bottom, edited by G. E. Bebout, D. W. Scholl, S. H. Kirby, and J. P. Platt, Geophysical Monograph 96, pp. 307-314, American Geophysical Union, Washington, 1996.

Kepezhinskas, P. K., M. J. Defant, and M. S. Drummond, Progressive enrichment of island arc mantle by meltperidotite interaction inferred from Kamchatka xenoliths, Geochim. Cosmochim. Acta, 60, 1217-1229, 1996.

Kepezhinskas, P. K., F. McDermott, M. J. Defant, A. Hochstaedler, M. S. Drummond, C. J. Hawkesworth, A. Koloskov, R. C. Maury, and H. Bellon, Trace element and $\mathrm{Sr}-\mathrm{Nd}-\mathrm{Pb}$ isotopic constraints on a threecomponent model of Kamchatka arc petrogenesis, Geochim. Cosmochim. Acta, 61, 577-600, 1997.

Kersting, A. B., and R. J. Arculus, Klyuchevskoy volcano, Kamchatka, Russia: The role of high-flux recharged, tapped, and fractionated magma chamber(s) in the genesis of high- $\mathrm{Al}_{2} \mathrm{O}_{3}$ from high-MgO basalt, $J$. of Petrology, 35, 1-41, 1994.

Kersting, A. B., and R. J. Arculus, Pb isotope composition of Klyuchevskoy volcano, Kamchatka, and North Pacific sediments: Implications for magma genesis and crustal recycling in the Kamchatkan arc, Earth Planet. Sci. Lett., 136, 133-148, 1995.

Kincaid, C., and P. Olson, An experimental study of subduction and slab migration, J. Geophys. Res., 92, 13832-13840, 1987.

Kirby, S. H., S. Stein, E. A. Okal, and D. C. Rubie, Metastable mantle phase transformations and deep earthquakes in subducting oceanic lithosphere, Rev. Geophys., 34, 261-306, 1996.

Kobayashi, R., and I. Nakanishi, Location of Love-toRayleigh conversion due to lateral heterogeneity or az- imuthal anisotropy in the upper mantle, Geophys. Res. Lett., 25, 1067-1070, 1998.

Kogan, M. G, G. M. Steblov, R. W. King, T. A. Herring, D. I. Frolov, S. G. Egorov, V. Ye. Levin, A. LernerLam, and A. Jones, Geodetic constraints on the rigidity and relative motion of Eurasia and North America, Geophys. Res. Lett., 27, 2041-2044, 2000.

Konstantinovskaya, E. A., Geodynamics of island arccontinent collision in the western Pacific margin, Geotectonics, 33, 353-370, 1999.

Konstantinovskaia, E. A., Arc-continent collision and subduction reversal in the Cenozoic evolution of the Northwestern Pacific: An example from Kamchatka, Tectonophys., 333, 75-94, 2001.

Kovalenko, D. V., Ya. Yu. Yaroslavtseva, and V. L. Zlobin, Paleomagnetism and tectonics of Karaginsky Island, Bering Sea, Geotectonics, 33, 81-94, 1999.

Kuzin, I. P., $P$ and $S$ wave velocities in the upper mantle of Kamchatka, Izvestia, Phys. Sol. Earth, 2, 69-75, 1973.

Lassiter, J. C., E. H. Hauri, P. W. Reiners, and M. O. Garcia, Generation of Hawaiian post-erosional lavas by melting of a mixed lherzolite/pyroxenite source, Earth Planet. Sci. Lett., 178, 269-284, 2000.

Lees, J. M., M. Brandon, J. Park, V. Levin, A. Ozerov, E. Gordeev, Kamchatka: Edge of the plate, IRIS Newsletter, 2000, 17-19, 2000.

Levashova, N. M., M. L. Bazhenov, and M. N. Shapiro, Late Cretaceous paleomagnetism of the East Ranges island arc complex, Kamchatka: Implications for terrane movements and kinematics of the northwest Pacific, $J$. Geophys. Res., 102, 24843-24857, 1997.

Levashova, N. M., M. N. Shapiro, V. N. Beniamovsky, and M. L. Bazhenov, Paleomagnetism and geochronology of the Late Cretaceous-Paleogene island arc complex Kronotsky Peninsula, Kamchatka, Russia; kinematic implications, Tectonics, 19, 834-851, 2000.

Levin, V., and J. Park, Crustal anisotropy in the Ural Mountains foredeep from teleseismic receiver functions, Geophys. Res. Lett., 24, 1283-1286, 1997.

Levin, V., and J. Park, $P-S H$ conversion in layered media with hexagonally symmetric anisotropy: A cookbook, Pure App. Geophys., 151, 669-697, 1998a.

Levin, V., and J. Park, Quasi-Love phases between Tonga and Hawaii: Observations, simulations and explanations, J. Geophys. Res., 103, 24321-24331, 1998b.

Levin, V., Menke, W., and Park, J., Shear wave splitting in the Appalachians and Urals: a case for multilayered anisotropy, J. Geophys. Res., 104, 17975-17994, 1999.

Levin, V., and J. Park, Shear zones in the Proterozoic lithosphere of the Arabian Shield and the nature of the Hales discontinuity, Tectonophys., 323, 131-148, 2000.

Levin, V., J. Park, J. Lees, M. T. Brandon, V. Peyton, E. Gordeev, and A. Ozerov, Crust and upper mantle of Kamchatka from teleseismic receiver functions, Tectonophys., accepted 2002. 
Lucente, F. P., C. Chiarabba, G. B. Cimini, D. Giardini, Tomographic constraints on the geodynamic evolution of the Italian region, J. Geophys. Res., 104, 2030720327, 1999.

Markov, M. S., V. A. Seliverstov, M. Yu. Khotin, and B. K. Dolmatov, Junction of east Kamchatka structures and the Aleutian Island arc, Geotectonics, 5, 314-319, 1969.

Marson-Pidgeon, K., M. K. Savage, K. Gledhill and G. Stuart, Seismic anisotropy beneath the lower half of the North Island, New Zealand, J. Geophys. Res., 104, 20277-20286, 1999.

Mather, A. M., Adjustment of a drainage network to capture induced base-level change; an example from the Sorbas Basin, SE Spain, J. Geomorphol., 34, 271-289, 2000.

McCaffrey, R. Estimates of modern arc-parallel strain rates in fore arcs, Geology, 24, 27-30, 1996.

Melankholina, E. N., The types of back-arc basins in East Asia: Tectonic, magmatic, and geodynamic aspects, Geotectonics, 32, 453-467, 1998.

Miyashiro, A., Volcanic rock series in island arcs and active continental margins, Amer. J. Sci., 274, 321-355, 1974.

Myers, J. D., and C. D. Frost, A petrologic re-investigation of the Adak volcanic center, central Aleutian arc, Alaska, J. Vol. Geoth. Res., 60, 109-146, 1994.

Nokleberg, W. J., and others, Summary Circum-North Pacific Tectonostratigraphic Terrane Map, scale 1:10000000, US Geological Survey Open File Report 96-727, 1997.

Nokleberg, W. J., L. M. Parfenov, J. W. H. Monger, I. O. Norton, A. I. Khanchuk, D. B. Stone, C. R. Scotese, D. W. Scholl, and K. Fujita, Phanerozoic Tectonic Evolution of the Circum-North Pacific, US Geol. Survey Prof. Paper 1626, 122 pp., 2001.

Northrup, C. J., L. H. Royden, and B. C. Burchfiel, Motion of the Pacific plate relative to Eurasia and its potential relation to Cenozoic extension along the eastern margin of Eurasia, Geology, 23, 719-722, 1995.

Otsuki, K., Empirical relationships among the convergence rate of plates, rollback rate of trench axis and island-arc tectonics: "Laws of the convergence of plates," Tectonophys., 159, 73-94, 1989.

Ozerov, A. Y., The evolution of high-alumina basalts of the Klyuchev-skoy volcano, Kamchatka, Russia, based on microprobe analysis of mineral inclusions, $J$. Volcanol. Geotherm. Res., 95, 2000.

Ozerov, A. Y., A. A. Ariskin, P. Kyle, G. E. Bogoyavlenskaya, and S. F. Karpenko, A petrological-geochemical model for genetic relationships between basaltic and andesitic magmatism of Klyuchevskoi and Bezymyannyi volcanoes, Kamchatka, Petrology, 5, 550-569, 1997.

Pacheco, J. F., L. R. Sykes, and C. H. Scholz, Nature of seismic coupling along simple plate boundaries of the subduction type, J. Geophys. Res., 98, 14133-14159, 1993.
Park, J. and Y. Yu, Seismic determination of elastic anisotropy and mantle flow, Science, 261, 1159-1162, 1993.

Park, J., and V. Levin, Receiver functions from multipletaper spectral correlation estimates, Bull. Seismol. Soc. Am., 90, 1507-1520, 2000.

Park, J., Free oscillations in an anisotropic earth: Pathintegral asymptotics, Geophys. J. Int., 129, 399-411, 1997.

Peacock, S. M., and K. Wang, Seismic consequences of warm versus cool subduction metamorphism: Examples from Southwest and Northeast Japan, Science, 286, 937-939, 1999.

Pechersky, D. M., N. M. Levashova, M. N. Shapiro, M. L. Bazhenov, and Z. V. Sharonova, Palaeomagnetism of Palaeogene volcanic series of the Kamchatsky Mys Peninsula, East Kamchatka: The motion of an active island arc, Tectonophys., 273, 219-237. 1997.

Peyton, V., V. Levin, J. Park, M. T. Brandon, J. Lees, E. Gordeev, and A. Ozerov, Mantle flow at a slab edge: Seismic anisotropy in the Kamchatka region, Geophys. Res. Lett., 28, 379-382, 2001.

Pineau, F., M. P. Semet, N. Grassineau, V. M. Okrugin, and M. Javoy, The genesis of the stable isotope $(\mathrm{O}, \mathrm{H})$ record in arc magmas: The Kamchatka case, Chemical Geology, 135, 93-124, 1999.

Plank, T., and C. H. Langmuir, An evaluation of the global variations in the major element chemistry of arc basalts, Earth Planet. Sci. Lett., 90, 349-370, 1988.

Plank, T., and C. H. Langmuir, The chemical composition of subducting sediment and its consequences for the crust and mantle, Chem. Geol., 145, 325-394, 1998.

Ribe, N. M., On the relationship between seismic anisotropy and finite strain, J. Geophys. Res., 97, 8737-8748, 1992.

Ribe, N. M., and U. R. Christensen, The dynamical origin of Hawaiian volcanism, Earth Planet. Sci. Lett., 171, 517-531, 1999.

Riegel, S. A., Fujita, K., Koz'min, B. M., Imaev, V. S., and D. B. Cook, Extrusion tectonics of the Okhotsk plate, northeast Asia, Geophys. Res. Lett., 20, 607-610, 1993.

Rotman, V. K., and B. M. Markovskiy, Potassium and rubidium in volcanic rocks of Kamchatka as indicators of late Cenozoic volcanotectonic evolution (in Russian), Doklady Akademii Nauk SSSR, 222, 917-920, 1975.

Royden, L., and B. C. Burchfiel, Are systematic variations in thrust belt style related to plate boundary processes? (The western Alps versus the Carpathians), Tectonics, 8, 51-61, 1989.

Russo, R. M. and P. G. Silver, Trench-parallel flow beneath the Nazca plate from seismic anisotropy, Science, 263, 1105-1111, 1994.

Russo, R. M. and P. G. Silver, Cordillera formation, mantle dynamics, and the Wilson cycle, Geology, 24, 511514, 1996. 
Savage, M., Lower crustal anisotropy or dipping boundaries? Effects on receiver functions and a case study in New Zealand, J. Geophys. Res., 103, 15069-15087, 1998.

Seliverstov, N. I., Geodynamic evolution of the junction zone of the Kuril-Kamchatka and Aleutian island arcs (in Russian), Vulkanologiya i Seysmologiya., 3, 12-17. 1997.

Seliverstov, N. I., Structure of Kamchatkian Water Area Bottom and Geodynamic of a Junction Zone between the Kuril-Kamchatka and Aleutian Island Arcs (in Russian), (164 p. 4 plates), Moscow, Nauchnyi Mir, 1998.

Seno, T., T. Sakurai, and S. Stein, Can the Okhotsk plate be discriminated from the North American plate? $J$. Geophys. Res., 101, 11305-11315, 1996.

Shapiro, M. N., Grechishkin overthrust on the shores of Kamchatka Gulf, Geotectonics, 14, 234-240, 1980.

Shapiro, M. N., The Upper Cretaceous AchaivayamianValaginian volcanic arc and kinematics of the North Pacific plates, Geotectonics, 29, 52-64, 1995.

Shapiro, M. N., D. M. Pechersky, and A. V. Lander, The rates and directions of absolute movements of subduction zones in the geologic past, Geotectonics, 31, 89-98, 1997.

Shapiro, N. M., A. V. Gorbatov, E. Gordeev, and J. Dominguez, Average shear-velocity structure of the Kamchatka peninsula from the dispersion of surface waves, Earth Planets and Space, 52, 573-577, 2000.

Silver, P. G., and W. W. Chan, Shear-wave splitting and subcontinental mantle deformation, J. Geophys. Res., 96, 16429-16454, 1991.

Sisson, T. W., and S. Bronto, Evidence for pressurerelease melting beneath magmatic arcs from basalt at Galunggung, Indonesia, Nature, 391, 883-886, 1998.

Soloviev, A. V., M. T. Brandon, J. I. Garver, and M. N. Shapiro, Kinematics of the Vatyn-Lesnaya Thrust Fault (Southern Koryakia), Geotectonics, 35, 471-489, 2001.

Stavsky, A. P., V. D. Chekhovich, V. Konovov, and L. P. Zonenshain, Plate tectonics and palinspastic reconstruction of the Anadyr-Koryakya region, northeast USSR, Tectonics, 9, 81-101, 1990.

Tatsumi, Y., Y. Furukawa, T. Kogiso, Y. Yamanaka, T. Yokoyama, and S. A. Fedotov, A third volcanic chain in Kamchatka: thermal anomaly at transform/convergence boundary, Geophys. Res. Lett., 21, 537-540, 1994.

Tatsumi, Y., T. Kogiso, and S. Nohda, Formation of a third volcanic chain in Kamchatka: Generation of unusual subduction-related magmas, Contrib. Mineral. Petrol., 120, 117-128, 1995.

Til'mann, S., and N. Bogdanov, Tectonic Map of Northeast Asia, scale 1:5,000,000, Institute of the Lithosphere, Russian Academy of Sciences and CircumPacific Council for Energy and Mineral Resources, Moscow, Russia, 29p., 1992.
Turner, S., F. McDermott, C. Hawkesworth, and P. Kepezhinskas, A U-series study of lavas from Kamchatka and the Aleutians: Constraints on source composition and melting processes, Contrib. Mineral Petrol., 133, 217234, 1998.

Utnasin, V. K., S. T. Balesta, E. N. Erlikh, G. I. Anosov, L. L. German, A. Ye. Shantser, The deep structure of the Kamchatka structural zone (in Russian), Sovetskaya Geologiya, 2, 67-80, 1975.

Van der Hilst, R. D., R. Engdahl, W. Spakman, and G. Nolet, Tomographic imaging of subducted lithosphere below northwest Pacific island arcs, Nature, 353, 37-43, 1991.

Vinnik, L. P., Kosarev, G. L., and Makeyeva L. I., Anisotropy of the lithosphere according to the observations of $S K S$ and $S K K S$ waves (in Russian), Doklady Akademii Nauk SSSR, 278, 1335-1339, 1984.

Volynets, O. N., Geochemical types, petrology and genesis of late Cenozoic volcanic rocks from the KurileKamchatka island-arc system, Int. Geol. Rev., 36, 373-405, 1994.

Watson, B. F., and K. Fujita, Tectonic evolution of Kamchatka and the Sea of Okhotsk and implications for the Pacific basin, in Tectonostratigraphic Terranes of the Circum-Pacific Region, edited by D. G. Howell, pp. 333-348, Houston, Texas, 1985.

Wiemer, S., G. Tytgat, M. Wyss, and U. Duenkel, Evidence for shear-wave anisotropy in the mantle wedge beneath south-central Alaska, Bull. Seismol. Soc. Am., 89, 1313-1322, 1999.

Wessel, P., and L. Kroenke, A geometric technique for relocating hotspots and refining absolute plate motions, Nature, 387, 365-369, 1997.

Wessel, P., and L. W. Kroenke, Ontong Java plateau and late Neogene changes in Pacific plate motion, J. Geophys. Res., 105, 28255-28277, 2000.

Wessel, P., and W. H. F. Smith, Free software helps map and display data, Eos Trans. AGU, 72, 441, 1991.

Winter, J. D., An Introduction to Igneous and Metamorphic Petrology, 679 pp., Prentice Hall, Upper Saddle River, USA, 2001.

Worrall, D., Tectonic history of the Bering Sea and the evolution of Tertiary strike-slip basins of the Bering Shelf, Geol. Soc. Amer. Special Paper, 257, 129p., 1991.

Worrall, D. M., V. Kruglyak, F. Kunst, and V. Kuznetsov, Tertiary tectonics of the Sea of Okhotsk, Russia: Farfield effects of the India-Eurasia collision, Tectonics, 15, 813-826, 1996.

Wortel, M. J. R., and W. Spakman, Subduction and slab detachment in the Mediterranean-Carpathian region, Science, 290, 1910-1917, 2000.

Wright, I. C., L. M. Parson, and J. A. Gamble, Evolution and interaction of migrating cross-arc volcanism and backarc rifting: An example from the southern Havre 
Trough $\left(35^{\circ} 20^{\prime}-37^{\circ} \mathrm{S}\right)$, J. Geophys. Res., 101, 22071$22086,1996$.

Yogodzinski, G. M., J. L. Rubenstone, S. M. Kay, and R. W. Kay, Magmatic and tectonic development of the Western Aleutians: An oceanic arc in a strike-slip setting, J. Geophys. Res., 98, 11807-11834, 1993.

Yogodzinski, G. M., R. W. Kay, O. N. Volynets, A. V. Koloskov, and S. M. Kay, Magnesian andesite in the western Aleutian Komandorsky region: Implications for slab melting and processes in the mantle wedge, GSA Bull., 107, 505-519, 1995.

Yogodzinski, G. M., J. M. Lees, T. G. Churikova, F. Dorendorf, G. Woerner, and O. N. Volynets, Geochemical evidence for the melting of subducting oceanic lithosphere at plate edges, Nature, 409, 500-504, 2001.

Yu, Y., and J. Park, Hunting for azimuthal anisotropy beneath the Pacific Ocean region, J. Geophys. Res., 99, 15399-15421, 1994.

Yuan, H., J. Park and V. Levin, Skidmarks of trenchparallel terrane migration: Subduction-zone anisotropy structure under Corvallis, Oregon, J. Geophys. Res., submitted 2002.

Zhang, S., and S.-I. Karato, Lattice preferred orientation of olivine aggregates deformed in simple shear, Nature, 375, 774-777, 1995.

Zhang, S., S.-I. Karato, J. FitzGerald, U. H. Faul, and Y. Zhou, Simple shear deformation of olivine aggregates, Tectonophys., 316, 133-152, 2000.

Zinkevich, V. P., and N. V. Tsukanov, The formation of the accretional structure of eastern Kamchatka in the late Mesozoic and early Cenozoic, Geotectonics, 26, 332-343, 1992.

Zinkevich, V., and N. Tsukanov, Accretionary tectonics of Kamchatka, Int. Geol. Rev., 35, 935-973, 1993.

Zonenshain, L. P., M. I. Kuzmin, and L. M. Natapov, Geology of the USSR: A Plate-Tectonic Synthesis, Geodynamics Series 21, 242 pp., American Geophysical Union, Washington DC, 1990.

Jeffrey Park, Vadim Levin, Mark T. Brandon, Dept. of Geology and Geophysics, Box 208109, Yale

University, New Haven, CT 06520 (email: jeffrey.park@yale.edu)

Jonathan M. Lees, Department of Geological Sci-

ences, Campus Box 3315, Mitchell Hall, Univ. of

North Carolina, Chapel Hill, NC 27599-3315

Valerie Peyton, U.S.G.S., Seismo Lab, Bldg 10002,

Kirtland AFB-East, Albuquerque, NM 87115

Evgenii Gordeev and Alexei Ozerov, Russian Academy

of Sciences, Far Eastern Branch, Petropavlovsk-Kamchatsky

Book chapter in press with "Plate Boundary Zones,"

edited by Seth Stein and Jeffrey Freymuller

\footnotetext{
${ }^{1}$ Yale University, New Haven, CT, USA

${ }^{2}$ University of North Carolina, Chapel Hill, NC, USA

${ }^{3}$ U.S. Geological Survey, Albuquerque, NM, USA
}

\footnotetext{
${ }^{4}$ Russian Academy of Sciences, Far Eastern Branch, Petropavlovsk-Kamchatsky, Russia
} 


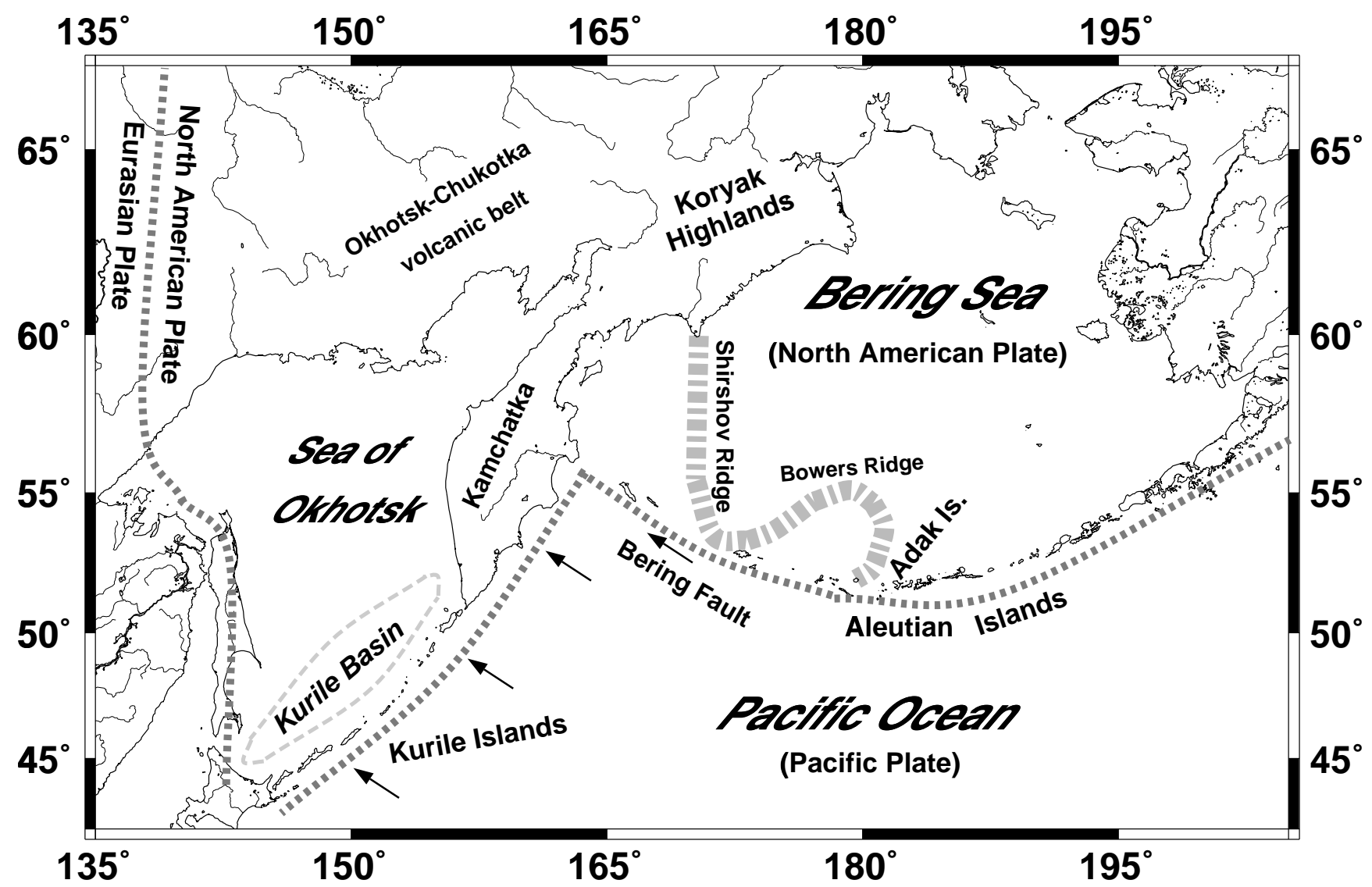

Figure 1. The North Pacific Region. The active boundary between the Pacific and North American plates (dashed grey line) extends westward from the Alaskan mainland along the Aleutians to Cape Kamchatka, and continues SW along the coast of southern Kamchatka to Northern Japan via the Kurile Island chain. The inferred boundary between the Eurasian and North American plates is indicated with a dashed grey line, based on DeMets [1992ab]. Arrows indicate the sense of present-day Pacific-plate motion, relative to North America. 


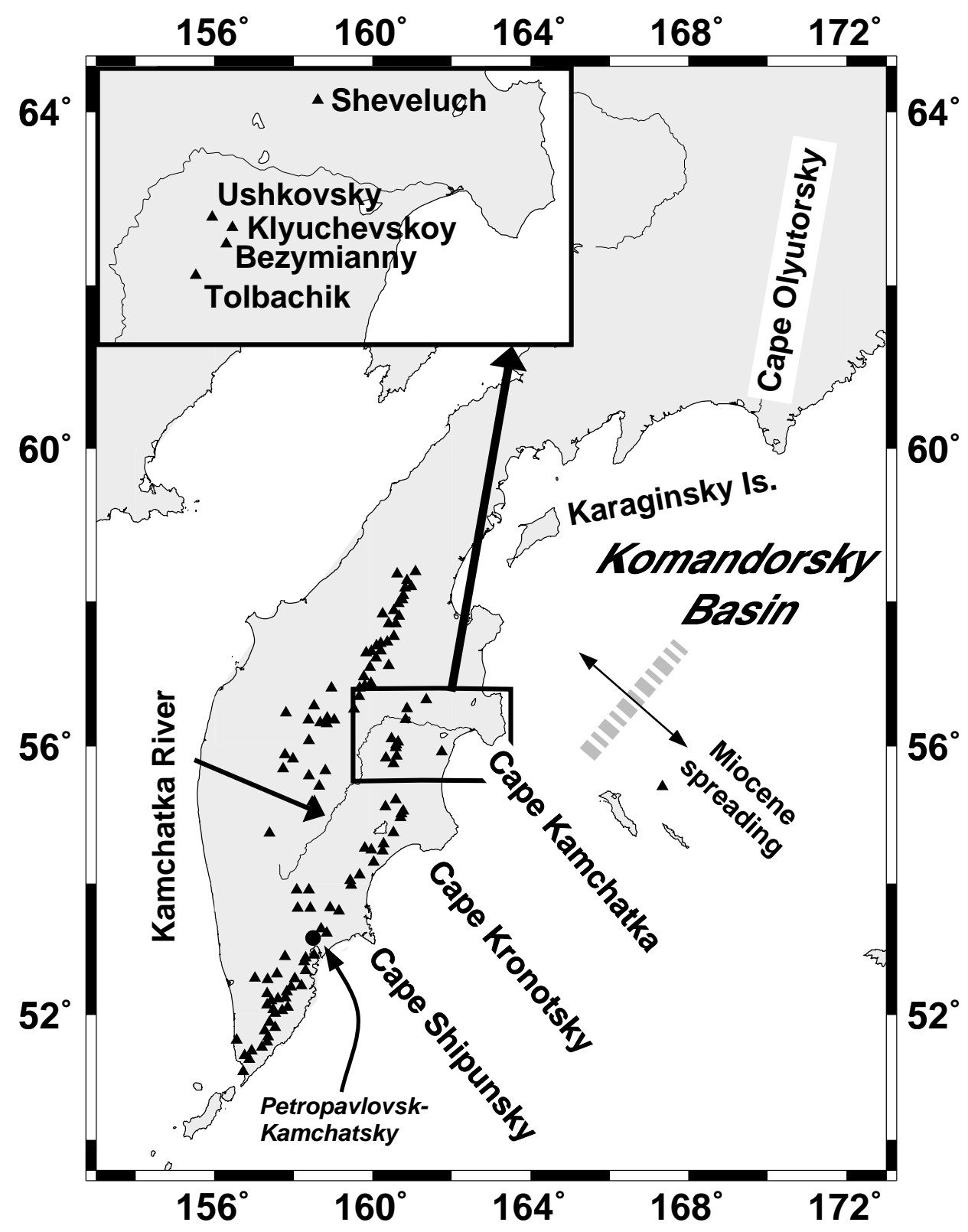

Figure 2. Map of Kamchatka. Solid triangles denote the location of volcanoes classified as "Holocene" in recent global compilations. However, the dates of past activity for inland volcanoes is poorly determined at present due to scarce radiometric dates. Erlich and Gorschov [1979] identify most inland activity as "Quaternary" based on stratigraphic constraints. The inset presents the major volcanoes of the Central Kamchatka Depression (CKD). 


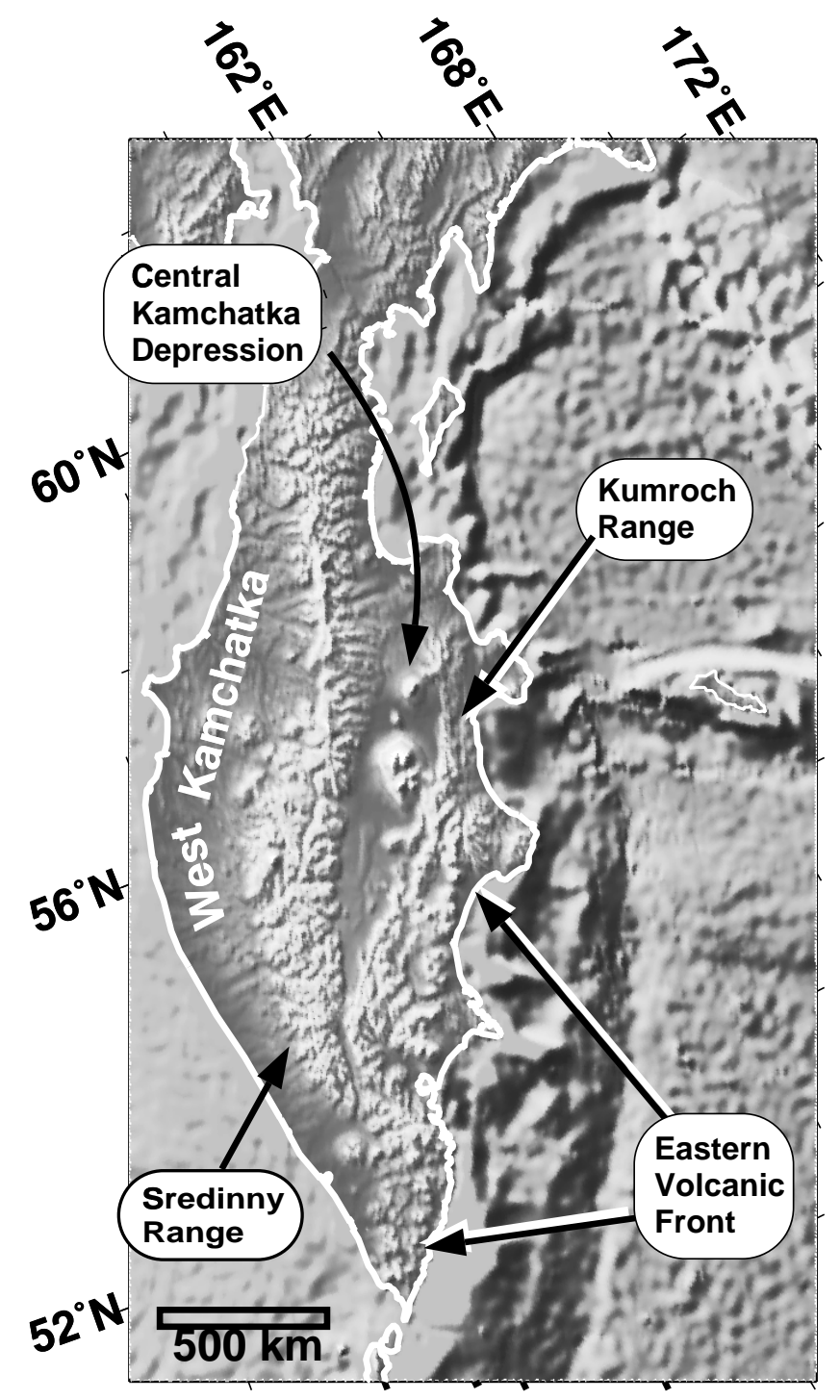

Figure 3. Topographic relief and major terranes of the southern Kamchatka peninsula. Solid triangles denote the location of volcanoes classified as "Holocene" in recent global compilations. However, the dates of past activity for inactive volcanoes in the Sredinny Range is poorly determined at present due to scarce radiometric dates. 


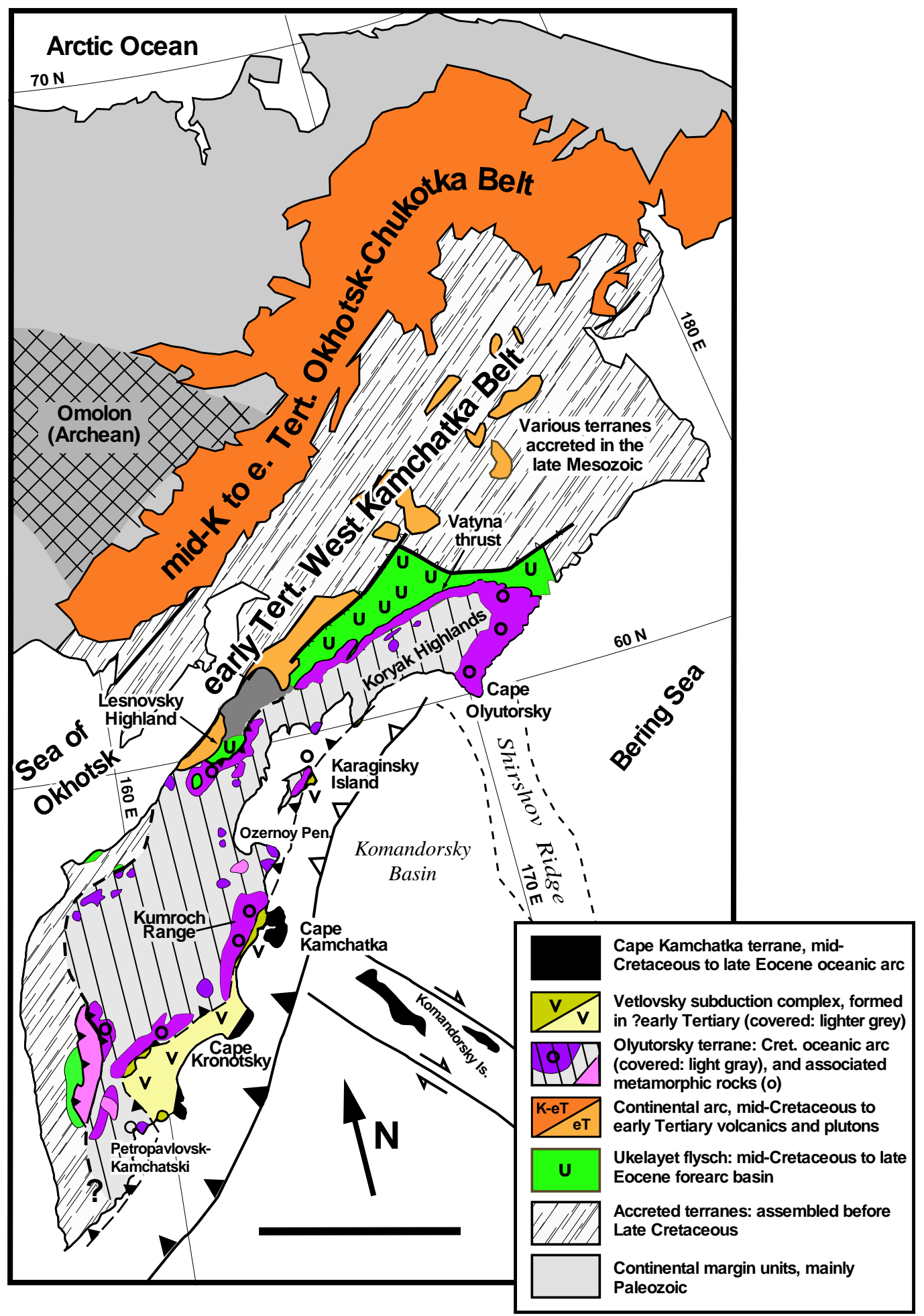

Figure 4. Tectonic map of the Kamchatka region, adapted from Garver et al. [2000]. The Russian Far East was formed by accretion of a succession of island-arc, ophiolitic and flysch terranes, starting in the Mesozoic. The last large terrane to arrive was the Olyutorsky terrane, which now straddles the Aleutian-Kamchatka junction. 


\section{Kamchatka-Kurile Seismicity}

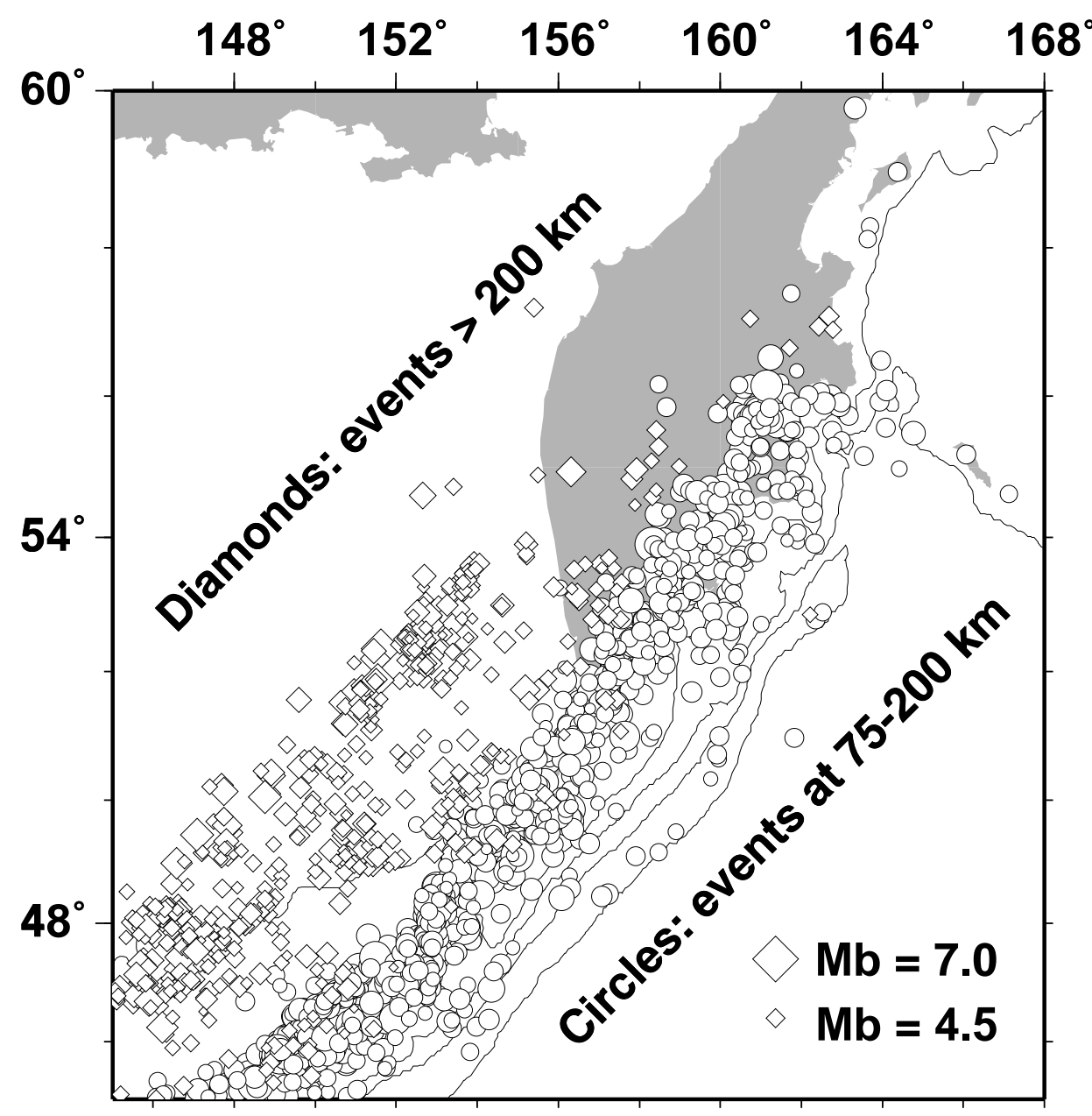

Figure 5. Intermediate $(75-200 \mathrm{~km})$ and deep $(>200 \mathrm{~km})$ earthquake epicenters for the Kamchatka region, located for the period 1964-1999 by Engdahl et al. [1998]. All events with $M>4.5$ in the catalog are plotted. Note the scarcity of deep earthquake hypocenters under the Kamchatka peninsula itself, suggesting the loss of the slab edge. 


\section{PET Receiver Function Sweeps, 2 Hz cutoff frequency}

Predicted polarity of slab Ps phase: triangle - Ps negative; circle - Ps positive

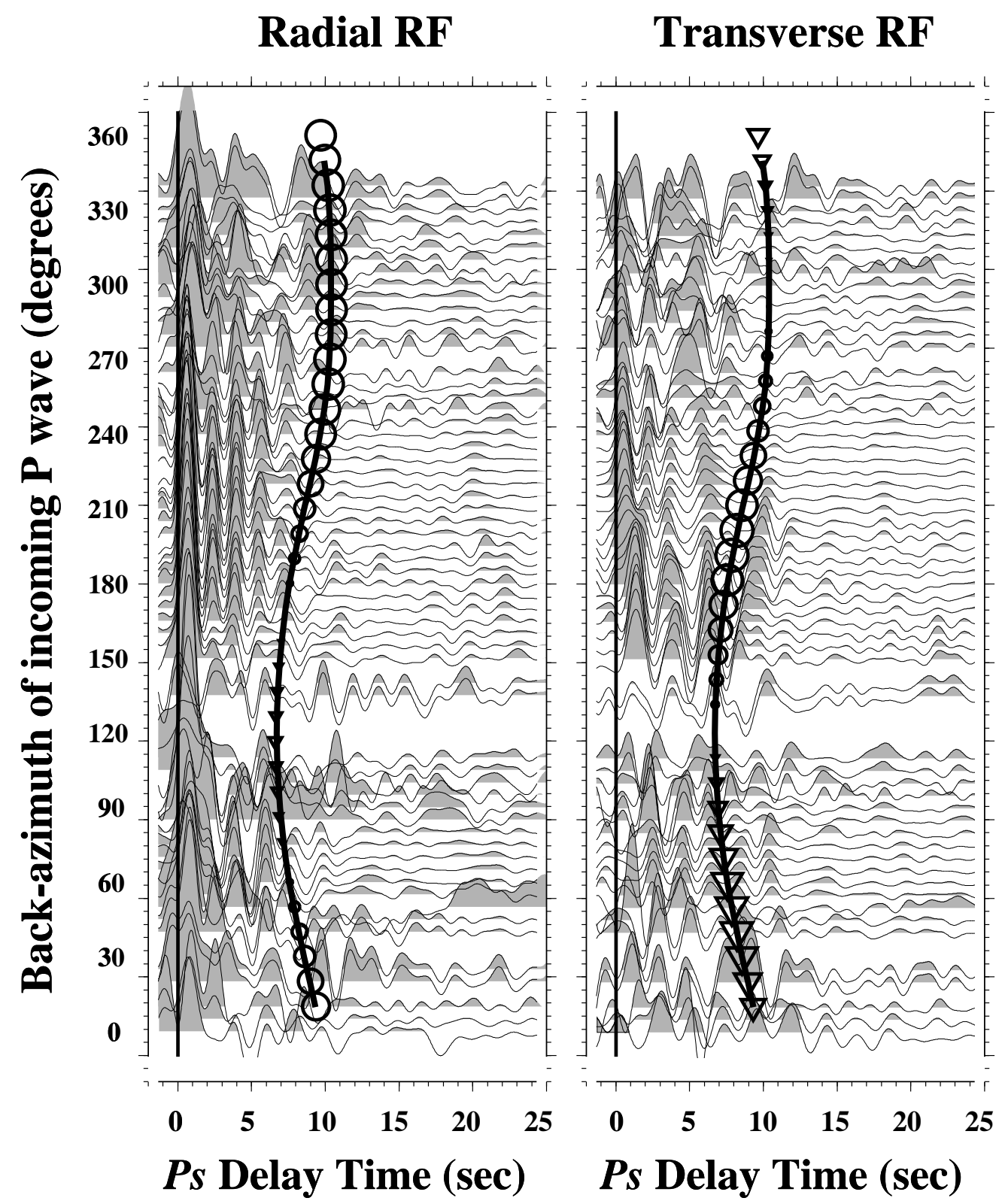

Figure 6. Back-azimuth dependence of receiver functions for station PET (Petropavlovsk-Kamchatsky, Russia). $P$-coda from 442 earthquakes at teleseismic distances were bin-stacked using the multiple-taper receiver function estimator of Park and Levin [2000]. Transverse RF amplitude is boosted by a factor of two for visual comparison. Note the strong transverse pulses at 7 - to 10 -sec time delay at $150^{\circ}-200^{\circ}$ back-azimuth. This signal appears to be a complex $P$-to- $S$ conversion from the steeply-dipping slab beneath PET. The curved line indicates the predicted delay and polarity for a $P s$ converted wave at the interface between a $55^{\circ}$-dipping slab and overlying mantle wedge. The polarity of the double-pulse conversion on the transverse RF is consistent with $P s$ conversions from the top and bottom of a low-velocity oceanic crust. 


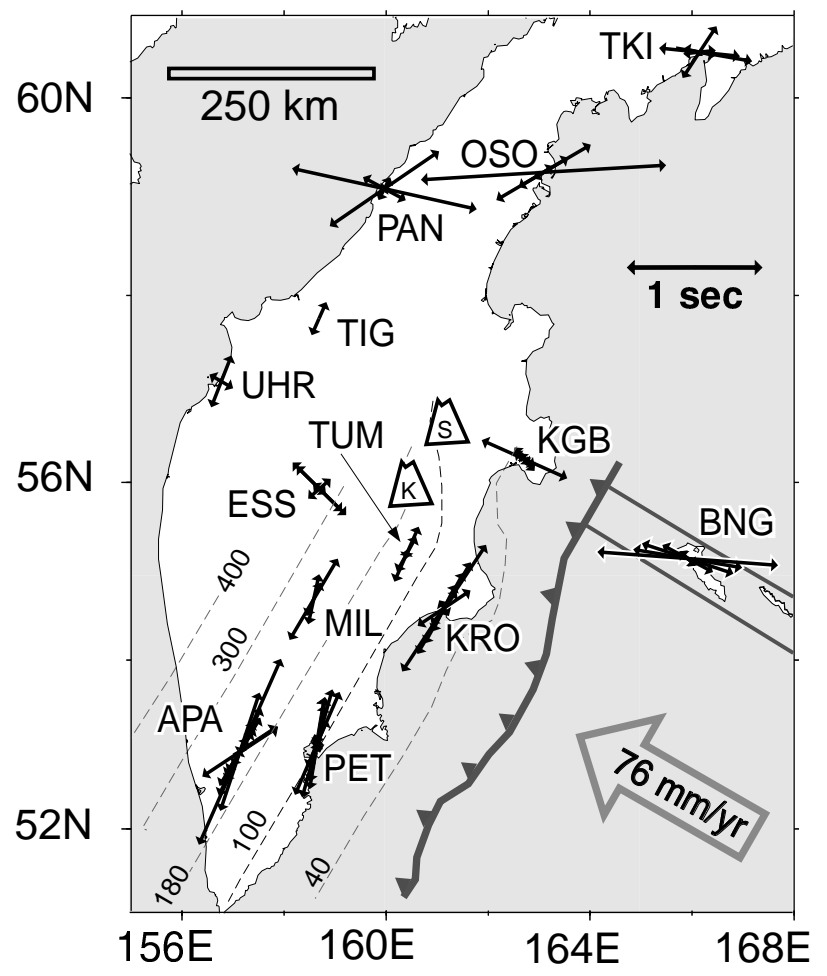

Figure 7. Shear-wave splitting observations at permanent seismological station PET and a portable broadband seismic network in Kamchatka region. Arrows represent single-record birefringence observations. The contours of the Wadati-Benioff zone under Kamchatka are adapted from Gorbatov et al. [1997]. The thick gray arrow shows the direction of Pacific plate motion (subduction along the Kamchatka trench and transcurrent motion along Bering Fault). The transcurrent boundary, distributed across the overriding North American plate [Geist and Scholl, 1994], is indicated by two thin grey lines. Two volcanoes are marked on the map: $K$-Klyuchevskoy; $S$ - Sheveluch. 


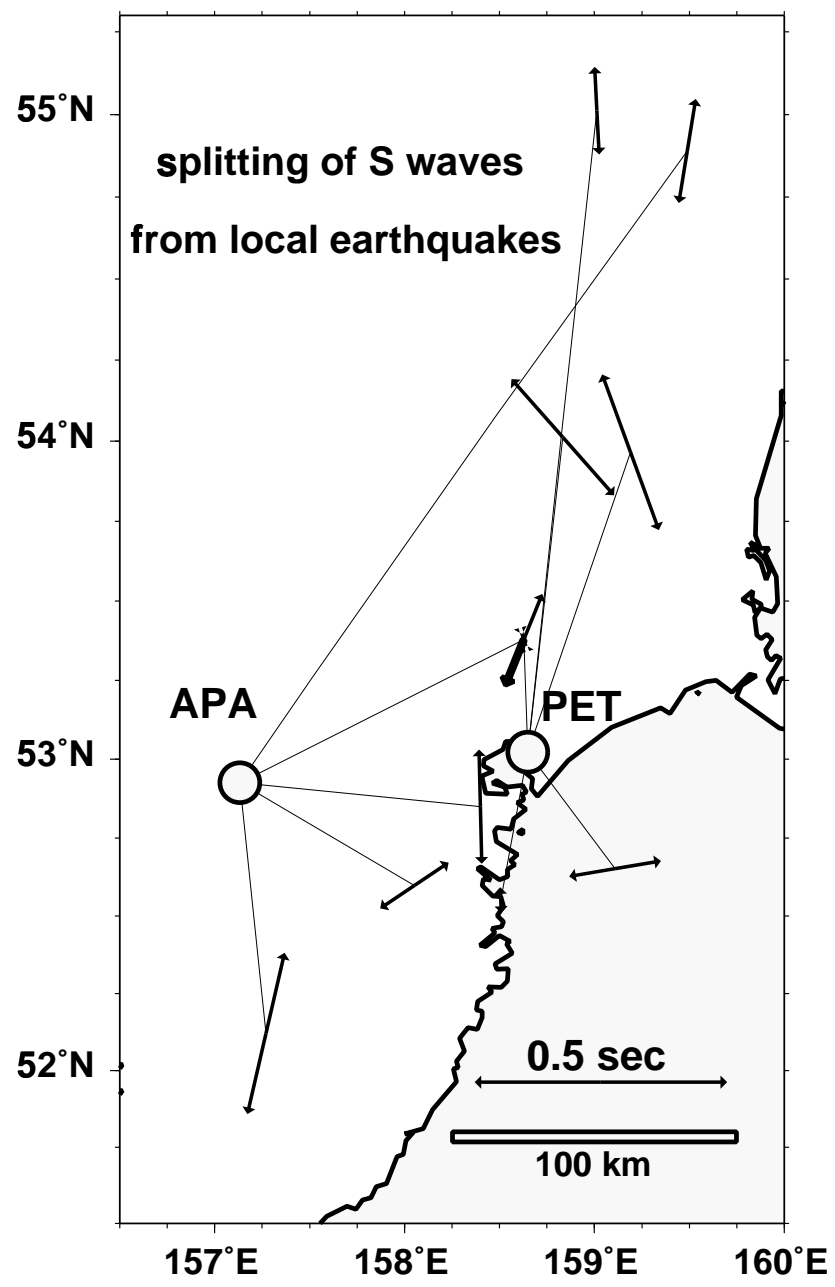

Figure 8. Shear-wave splitting observations from local $S$ waves at stations APA and PET. Arrows represent singlerecord birefringence observations, placed at the epicenter of earthquakes in the Kamchatka subduction zone. Locations are from the reviewed catalog of the Kamchatka Experimental-Methodical Seismic Department (KEMSD). Note the scale difference for splitting delay $\delta t$ relative to Figure 7. 

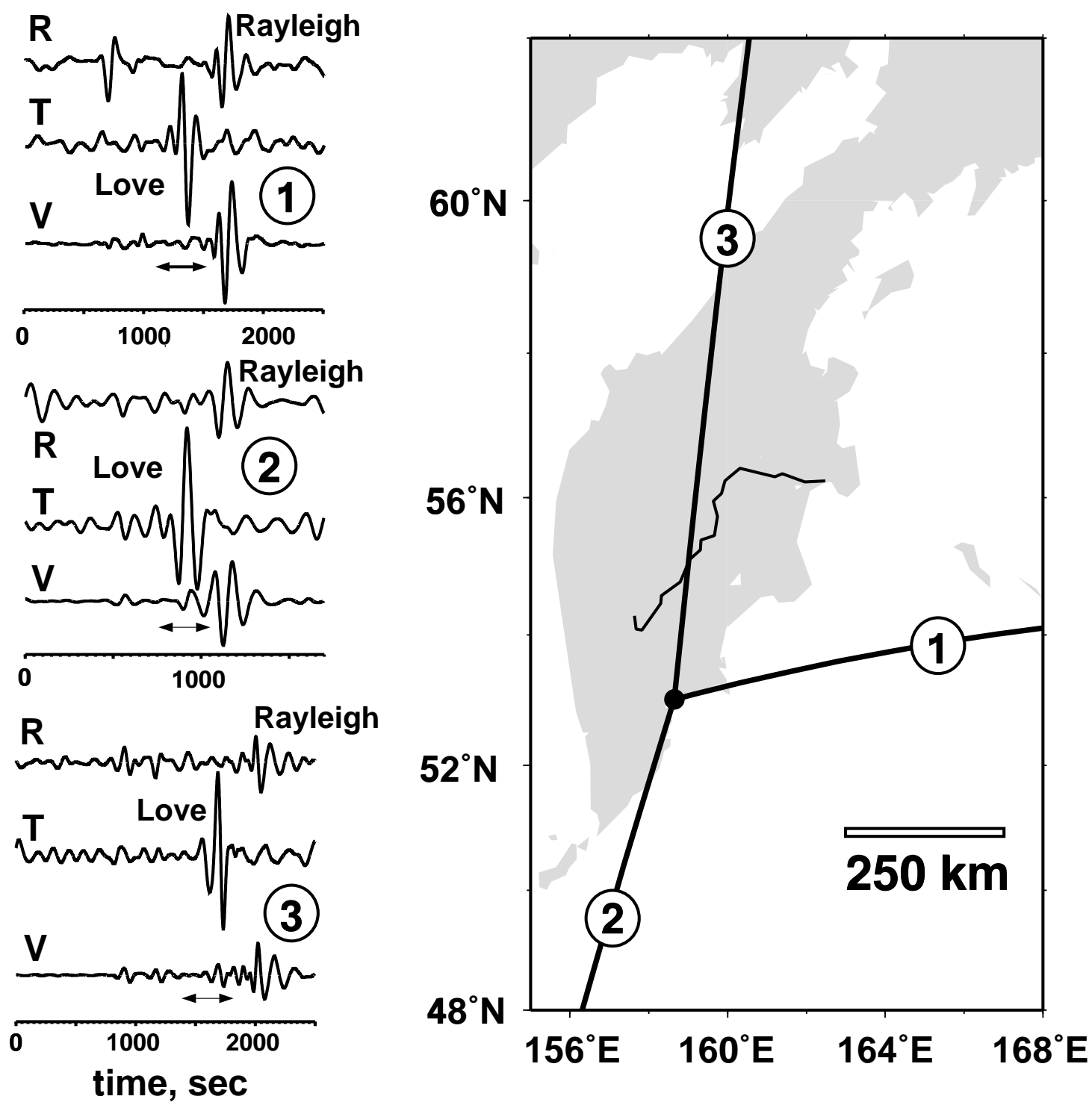

Figure 9. Quasi-Love waves observed (and not observed) at GSN station PET (Petropavlovsk-Kamchatsky). Horizontal motion is plotted for the radial $(\mathrm{R})$ and transverse $(\mathrm{T})$ directions. The expected time windows for quasi-Love waves on the vertical (V) components are indicated by arrows beneath the Love waves. A quasi-Love scattered wave is most evident for event (3), at northerly back-azimuth. The QL wave for event (3) is distinguished by an early pulse on the vertical component that separates from the main Rayleigh wave. In contrast, the Rayleigh wave for event (2) extends into the Love-wave window, but waveform appears to be spread by dispersion, not a precursory phase. Events (1) and (2) approach at roughly $45^{\circ}$ and $135^{\circ}$ to the Kamchatka trench, optimal backazimuth for Love-Rayleigh scattering by a local concentration of anisotropy with a trench-parallel fast-polarization. 


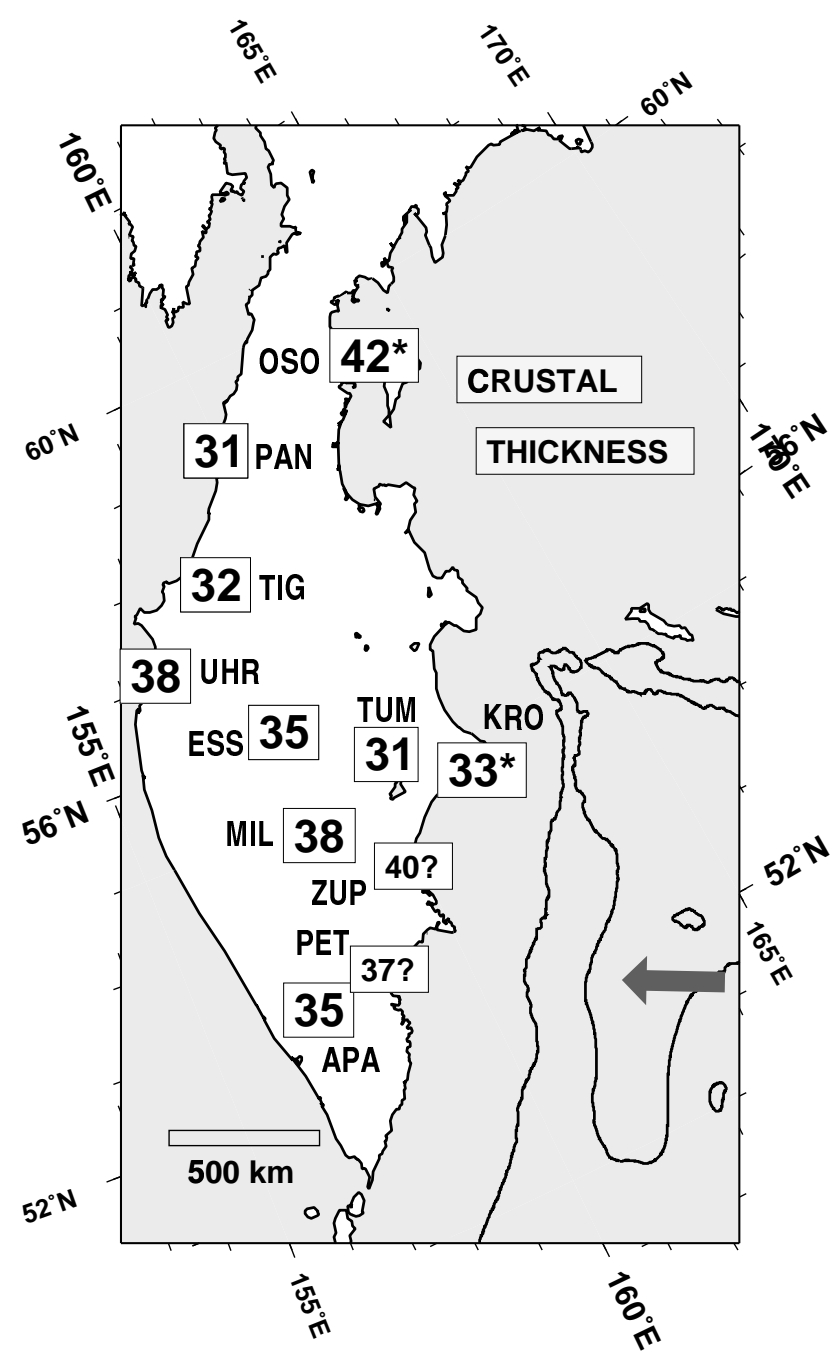

Figure 10. Crustal thickness values derived from individual models. Depth to the bottom of the lowest layer with $V_{S}<4.0 \mathrm{~km} / \mathrm{s}$ is shown. Asterisks mark sites where we believe the transition is gradational. Values for ZUP and PET are derived on the basis of comparing their transverse RFs with that of KRO, and thus are shown with a question mark. Black arrow shows the direction of convergence along the Kamchatka trench. Thin black lines in the ocean denote the depth contour of $5500 \mathrm{~m}$, providing an outline of the Kamchatka and Aleutian deep-water trenches. 


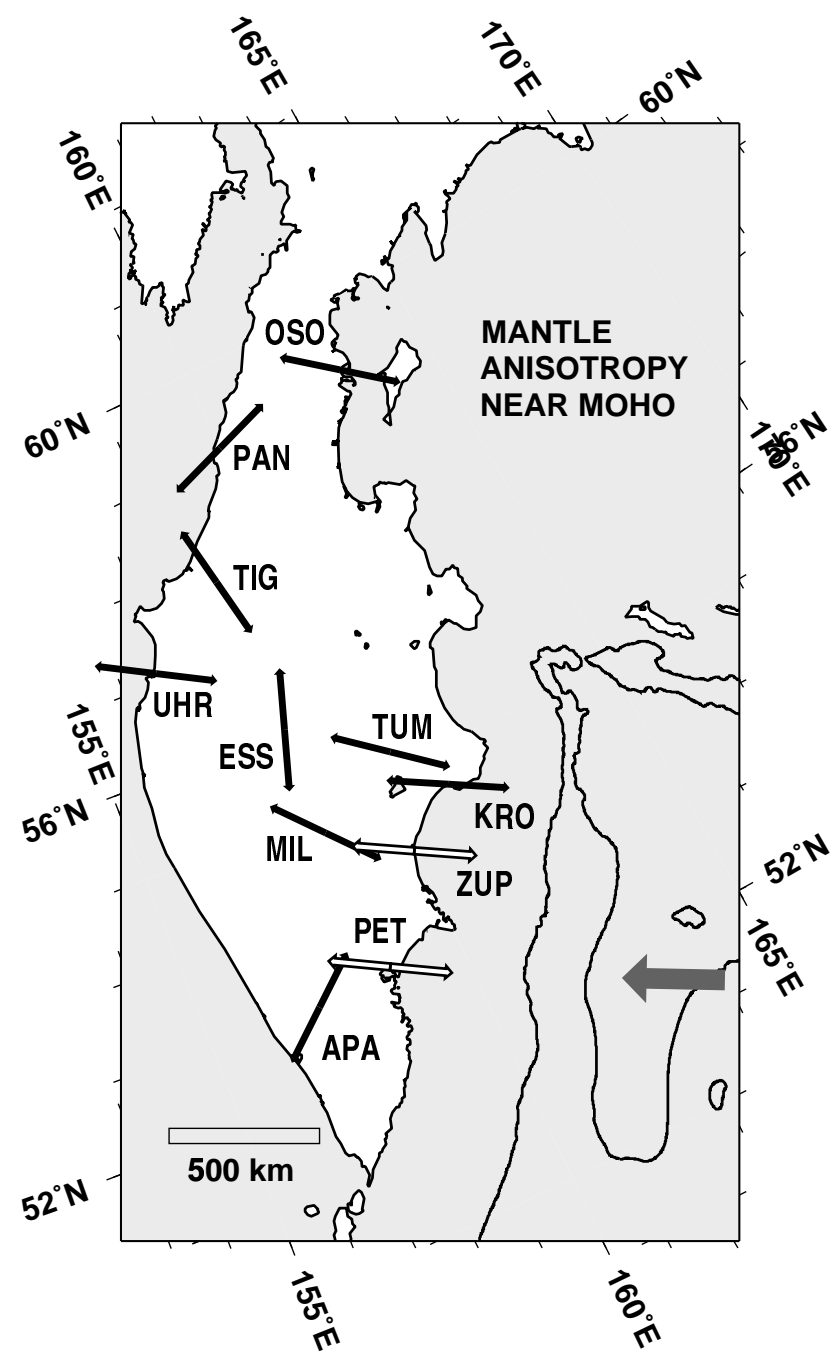

Figure 11. Seismic anisotropy orientation in the upper mantle under Kamchatka. Orientations of anisotropic symmetry axes derived from individual models are plotted by black arrows centered on sites. Open arrows at ZUP and PET show directions inferred through comparative analysis of transverse RFs for PET, ZUP and KRO. Black arrow shows the direction of convergence along the Kamchatka trench. Thin black lines in the ocean denote the depth contour of $5500 \mathrm{~m}$, providing an outline of the Kamchatka and Aleutian deep-water trenches. 


\section{CRUST AND UPPER MANTLE OF KAMCHATKA PENINSULA}

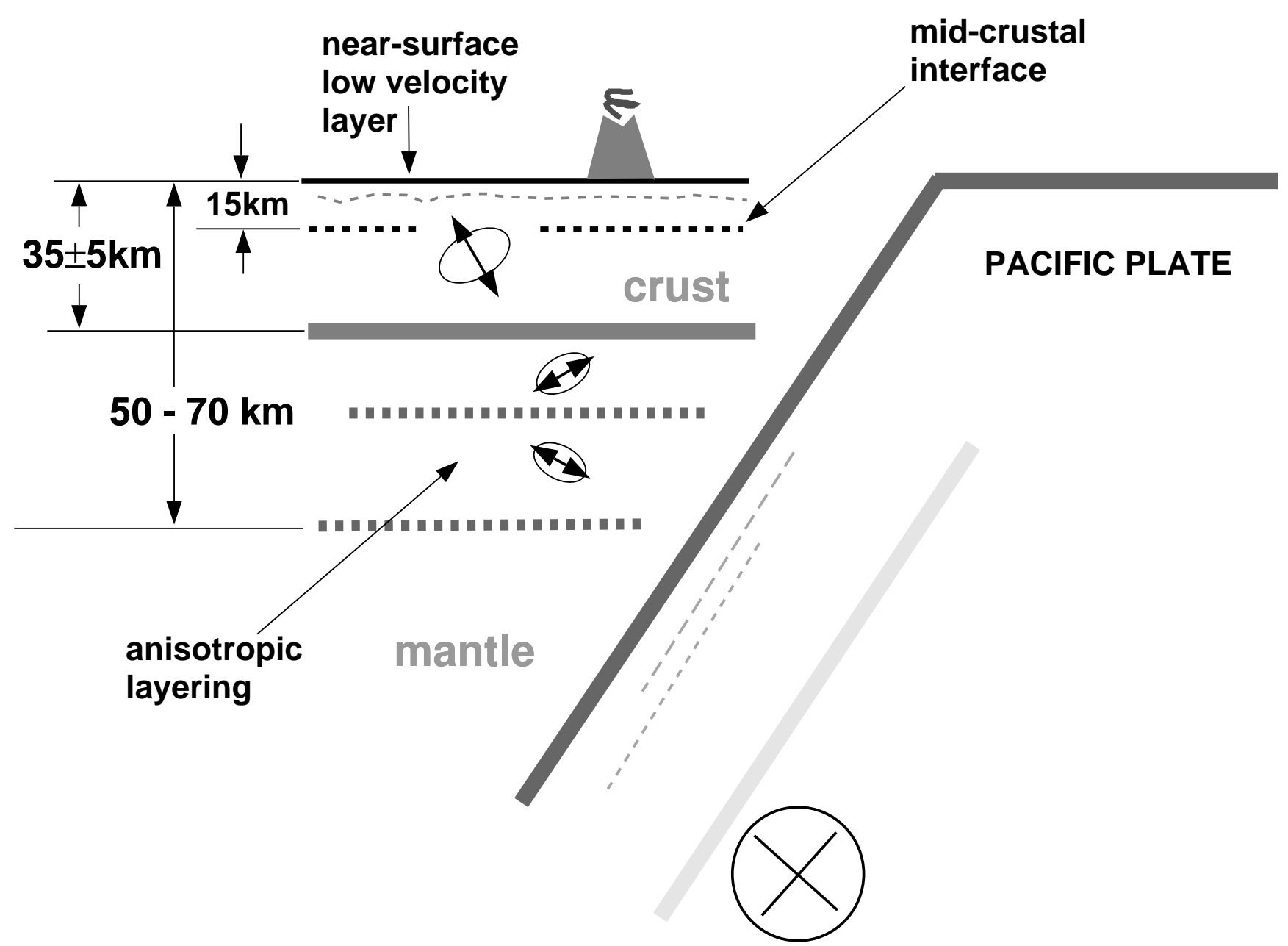

sub-slab flow

Figure 12. Summary cartoon of seismic anisotropy orientation in the upper mantle wedge beneath Kamchatka. Sub-slab anisotropy is inferred from $S K S$ splitting. Mantle wedge and crustal fabric are inferred from receiverfunction analysis of data from the SEKS portable seismic network. $P$-to- $S H$ converted phases from all mantle-wedge layer interfaces are not observed at all stations, but RFs from stations along the Eastern Volcanic Front exhibit qualitatively similar features. 


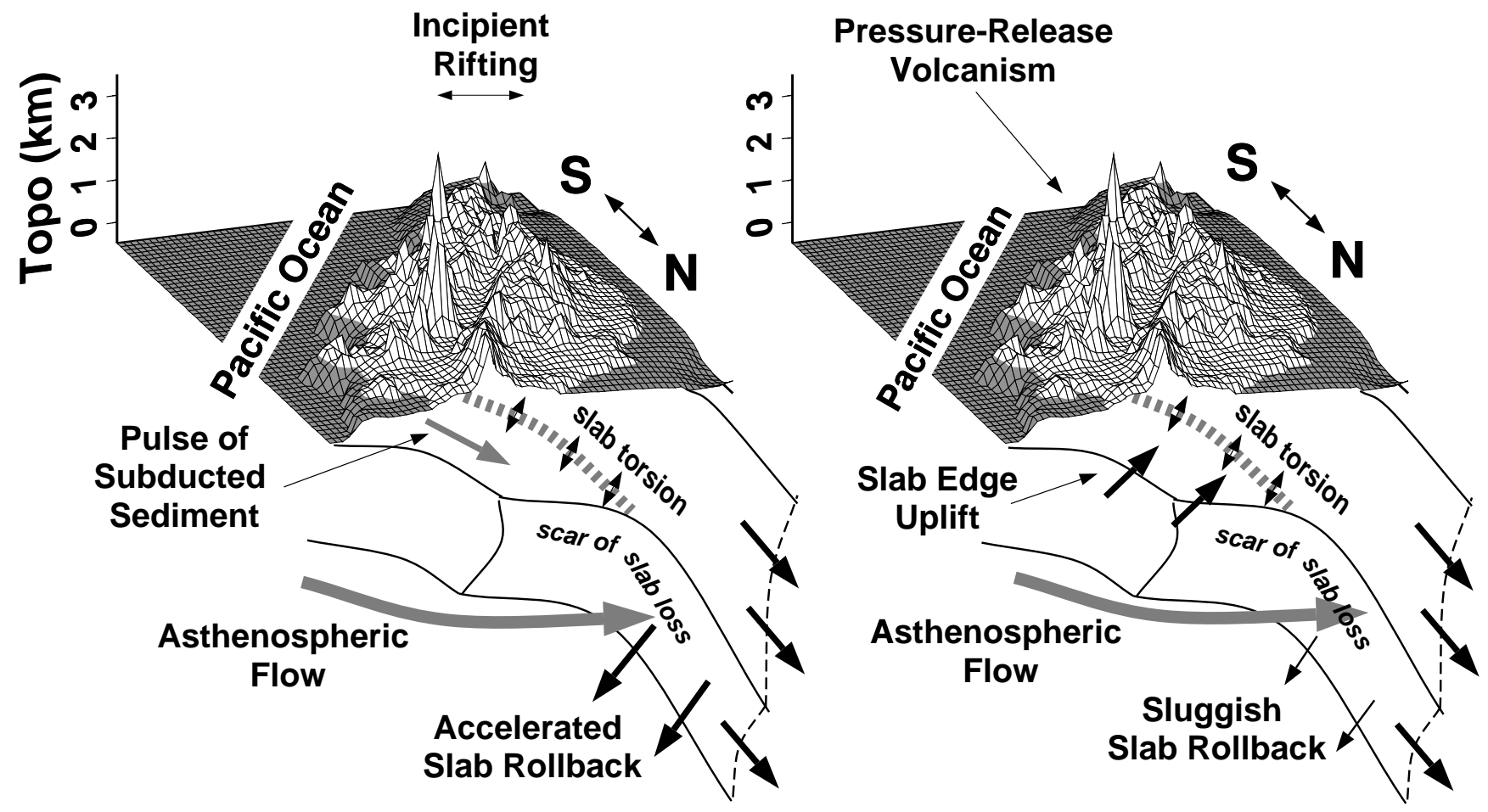

Figure 13. Schematic representation of competing scenarios for Quaternary volcanism and tectonics near the Kamchatka slab edge. Left: accelerated slab rollback and volatile transport into the mantle wedge. Right: slabedge pinchoff and the upward rebound of its remnant. 

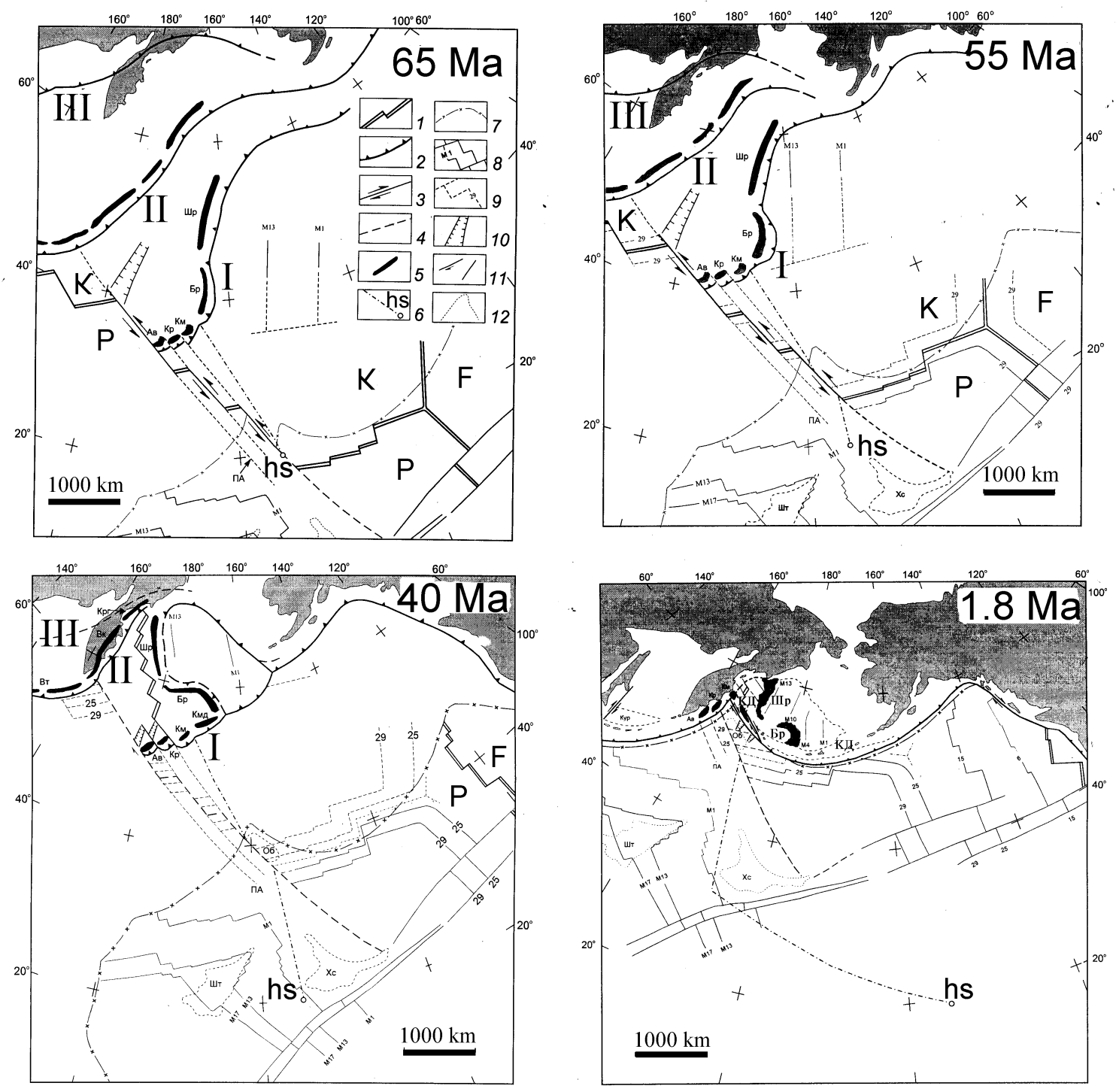

Figure 14. Plate reconstruction for the north Pacific from Seliverstov [1998]. Legend in the 65 Ma map: 1) active spreading center, 2) subduction zone, 3) transform fault, 4) trace of the Hawaiian hotspot, 5) oceanic volcanic arc, 6) Hawaiian hotspot (hs), (7) line marking material points that currently lie at the Aleutian-KamchatkaKuril subduction zones, (8) magnetic lineations with major chrons labeled, (9) inferred magnetic lineations, (10) grabens, (11) minor faults, and (12) outline of oceanic plateaux. Abbreviations for oceanic plates: $\mathrm{K}, \mathrm{F}, \mathrm{P}=$ Kula, Farallon, and Pacific. Oceanic plateaux: Xc $=$ Hess rise; $\mathrm{WT}=$ Shatsky rise. Active subduction zones: $\mathrm{I}=$ Cape Kamchatka oceanic arc, II = Olyutorsky oceanic arc, III = continental subduction zone along northeastern Asia margin. Components of the Cape Kamchatka arc, from north to south in lower left panel: Shirshov ridge, Bowers ridge, Komandorsky Islands (western Aleutians), Cape Kamchatka terrane, Cape Kronotsky terrane, Cape Shipunsky terrane. Emperor seamount chain indicated by dashed line that extends from Hawaiian hotspot (hs). 


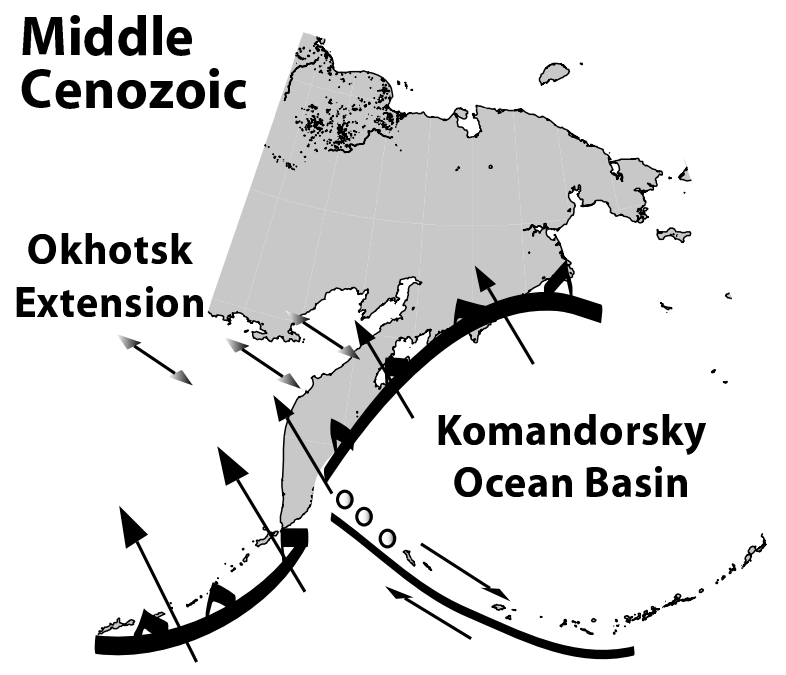

Pacific Plate

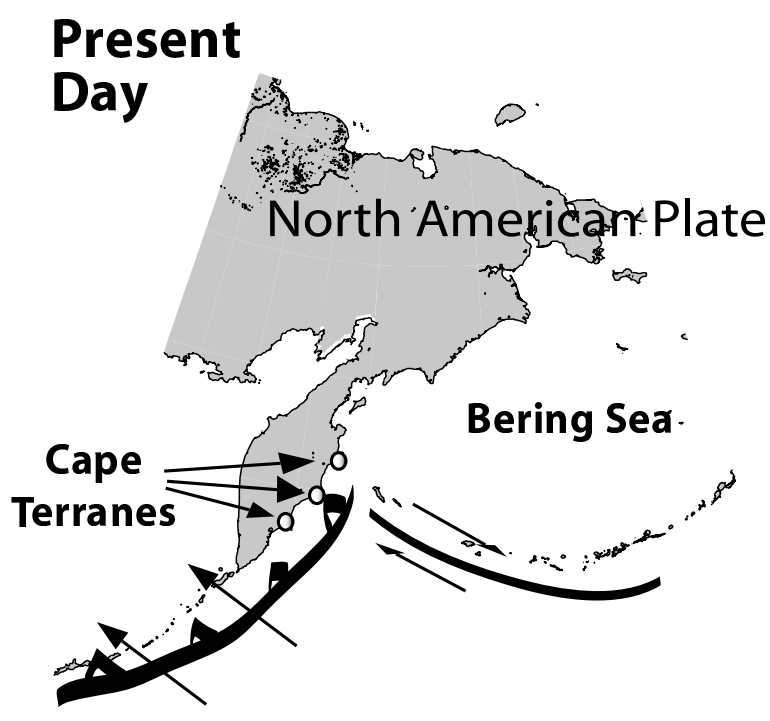

Pacific Plate

Figure 15. Plate reconstruction for hypothesized late-Cenozoic tectonics of the Kamchatka region. Left: The first of the present-day "Cape" terranes (Shipunsky) collides with the Kamchatka peninsula, which has rotated $\mathrm{CCW}$ in response to extension in the Sea of Okhotsk. Collision timing is poorly constrained, but extrapolating the Pacific absolute plate motion proposed by Wessel and Kroenke [2000] suggests 25-30 Ma. Active subduction of the Komandorsky Basin occurs along the full eastern Kamchatka coastline. Subducted Komandorsky Basin is young and buoyant, fostering shallow slab dip and the formation of a volcanic arc (Sredinny Range) far inland. Pacific plate motion has a component normal to the Bering Fault, but rather than resume subduction under the western Aleutians, the Komandorsky plate drifts NE in response. Right: Cape terranes accrete sequentially onto the Kamchatka coast. Pacific plate changes direction during 2-6 Ma in response to collision of the Ontong Java Plateau with the Solomon subduction zone. As a result, the remnant of the Komandorsky Basin no longer subducts into the north Kamchatka subduction zones, and island-arc volcanism ceases. 